\title{
He oro hauora: How do kaupapa Māori models of health relate to my music therapy practice in an adolescent acute mental health unit?
}

\author{
Nolan Hodgson
}

An exegesis submitted to Massey University and Victoria University of

Wellington in partial fulfilment of the requirements for the degree

Master of Music Therapy

New Zealand School of Music 



\section{Abstract:}

This project explores the relationship between understandings of health within kaupapa Māori frameworks and music therapy with a particular focus on Durie's Te Whare Tapa Whà (1998), Pere's Te Wheke (1991) and ecological perspectives in music therapy. This research took place within an acute adolescent mental health unit that operates with a model of healthcare that emphasises Māori approaches to wellbeing. Secondary analysis of data involving techniques developed within grounded theory is used to investigate clinical notes from my music therapy practice in order to identify processes relevant to the four dimensions of Te Whare Tapa Wha . Themes that emerged were examined and used to investigate further data until a clearer picture of the relationship between music therapy and kaupapa Māori health frameworks became evident. This project particularly acknowledges the unique qualities of music and its practical application in music therapy in order to address and support a person's wairua within modern mental health practices. Specifically, the concepts of mana, mauri and whatumanawa appeared particularly relevant to the process of music therapy and the state of whakamā also emerged as significant within this mental health context. Parallels between kaupapa Māori understandings of health and ecological perspectives within music therapy were also noted and particular reference made to the work of Carolyn Kenny and her Field of Play (2006) model in developing the discourse linking indigenous perspectives with the music therapy profession. 


\section{Table of Contents:}

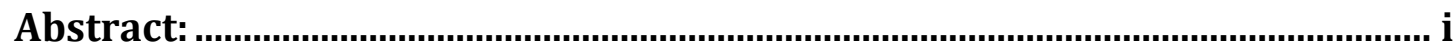

Table of Contents: …..................................................................................

Mihimihi

Ethics Statement

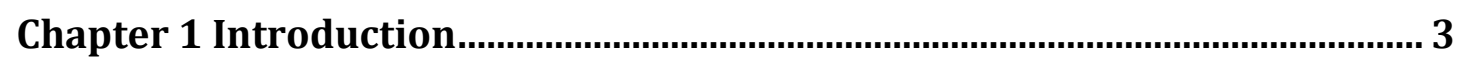

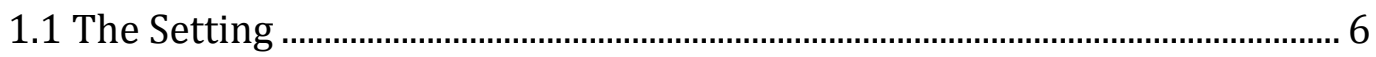

1.2 Music Therapy with Adolescents in Mental Health Contexts.......................... 7

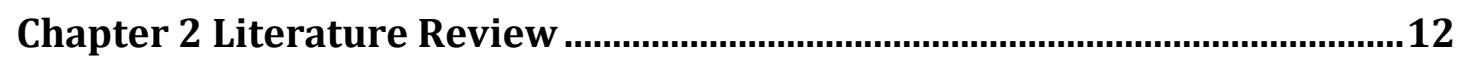

2.1 Indigenous Mental Health .........................................................................................12

2.2 Policy Responses in Aotearoa ....................................................................................13

2.3 Music Therapy and Hauora Māori ......................................................................15

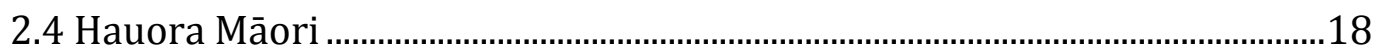

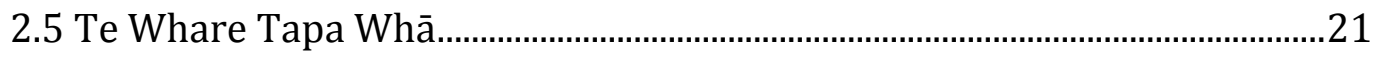

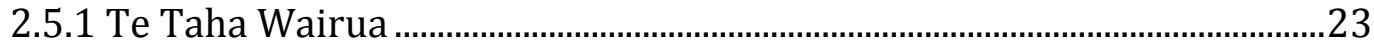

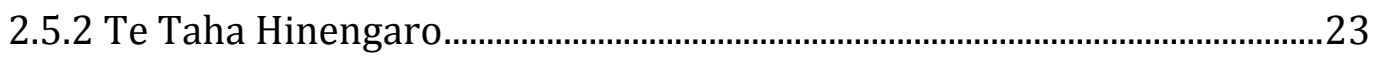

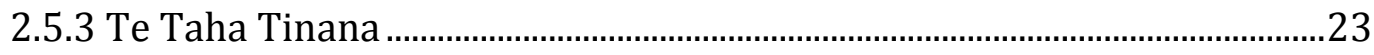

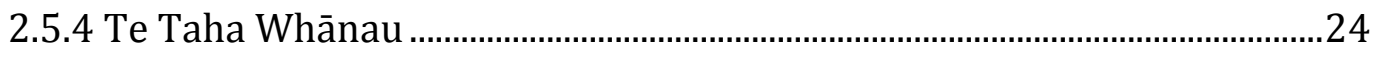

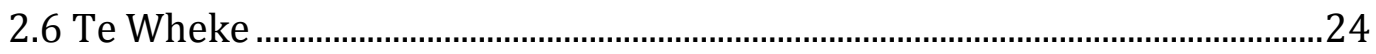

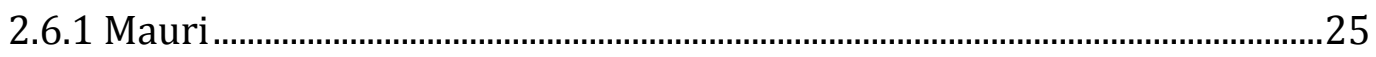

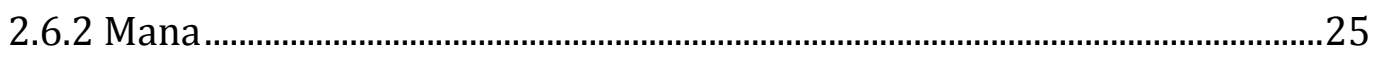

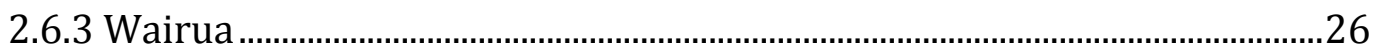

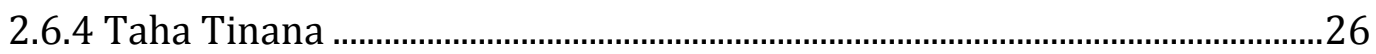




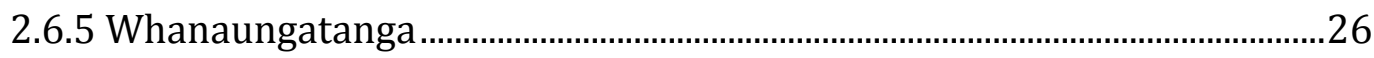

2.6.6 Hā a koro mā, a kui mā .....................................................................................27

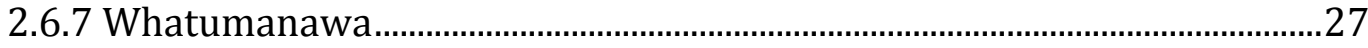

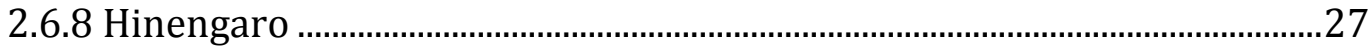

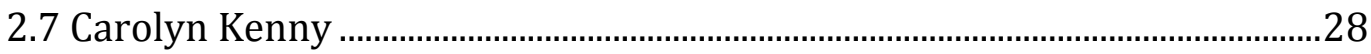

2.8 Music Therapy and Traditional Healing Practices.........................................30

2.9 Ecological Perspectives in Music Therapy .........................................................32

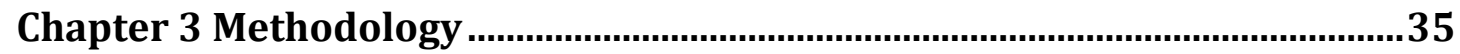

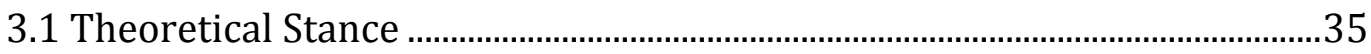

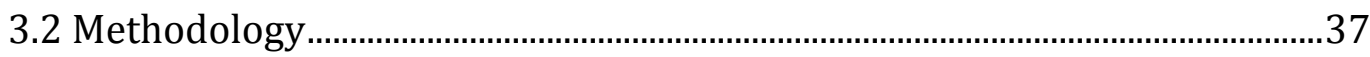

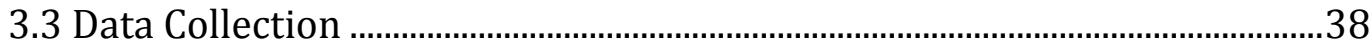

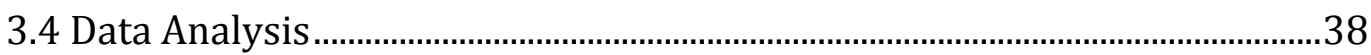

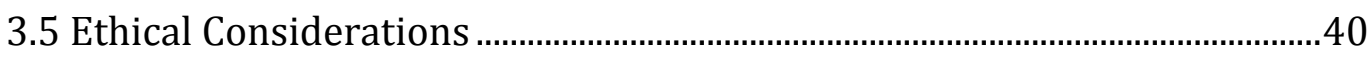

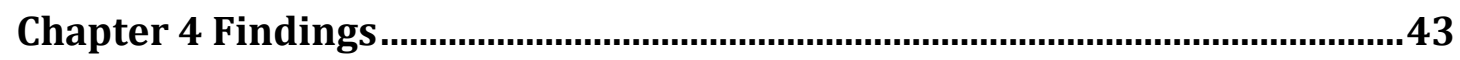

4.1 Wairua - The capacity for faith and wider communication. .........................47

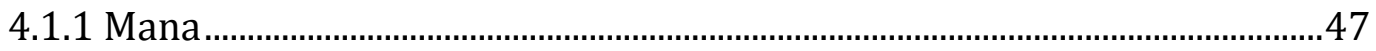

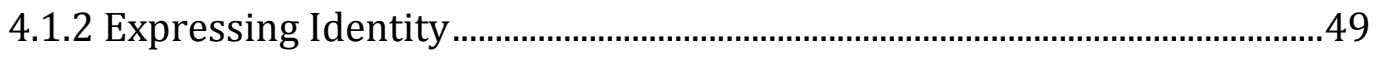

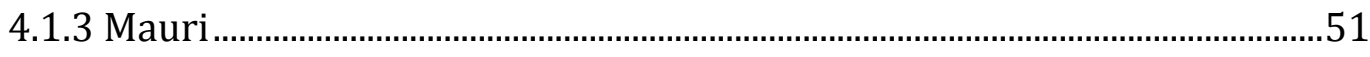

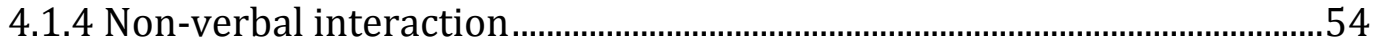

4.1.5 Expressing links with environment and cultural heritage ........................55

4.2 Whānau - Capacity to belong, to care and to share as part of wider social systems

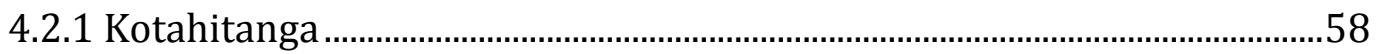

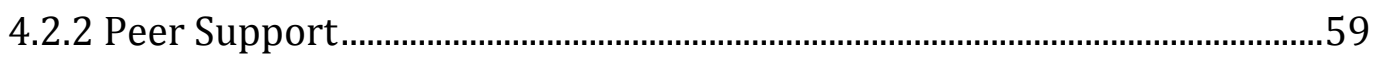


4.3 Tinana - Capacity for physical growth and development.

4.3.1 Physical Activities.

4.3.2 Physicality of Instruments 63

4.4 Hinengaro - Capacity to communicate, to think and to feel emotions......65

4.4.1 Thinking and Feeling .66

4.4.2 Cognitive Tasks. 67

4.4.3 Boundaries 68

Chapter 5 Vignette .70

Chapter 6 Discussion. .77

6.1 Strengths, Limitations 87

6.2 Conclusion 88

7 Glossary. .90

8 References. .93

Appendix One: Consent for Use of Information for Vignette. 103

Appendix Two: Parental Consent Form for Vignette. 105

Appendix Three: Example of Deductive Codes from Data Analysis 107

Appendix Four: Example of Analytic Memos 108 


\section{Figures, Tables and Diagrams}

Figure 1: Whakapapa of Creation, Marsden (2003) ................................................... 20

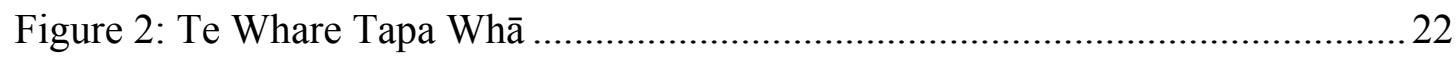

Table 1: Guidlines for researchers according to kaupapa Māori principles ................ 42

Table 2: Identified needs and aims for a music therapy group in an acute mental

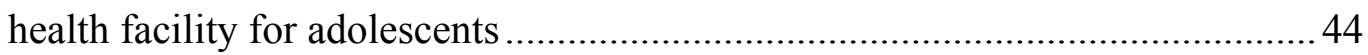

Diagram 1: Theoretical Categories \& Codes relating to the dimension of Wairua..... 47

Diagram 2: Theoretical Categories \& Codes relating to the dimension of Whānau ... 57

Diagram 3: Theoretical Categories \& Codes relating to the dimension of Tinana ..... 62

Diagram 4: Theoretical Categories \& Codes relating to the dimension of Hinengaro 65 


\section{Mihimihi}

Ka tangi te tîtī, ka tangi te kākā, ka tangi hoki ko au. Tihei mauri ora.

E tōku kuia kua whetūrangitia, ko Betty Hodgson.

Moe mai i te poho o te Atua. Haere atu rā i ngā kapua e rere ki tua ki Hawaiki nui, ki Hawaiki roa, ki Hawaiki-pamaomao, ki te tauranga o te wairua. Haere, haere, haere atu rā.

Tēnā koe.

E ngā rangatira, ko Sarah koutou ko Mike, ko Daphne.

Ngā mihi mahana ki a koutou e arotahi ana i ngā whakaaro ki roto i tēnei pūrongo. Ka patua te mōnehunehu, ka pūrangiaho te kitea o te huarahi.

Kei te mihi, kei te mihi.

E tōku kaiako, tōku hoa hoki, ko Serahn.

Nā tō reo waitī i whakakā taku hihiri. Me mihi kau ana ki a koe i whakatō ai i te kākano o tēnei rangahau mō te pūtahitanga mai i te mātauranga Māori ki te mātauranga o te rōpū puoro whakaora.

Kei te mihi, kei te mihi.

He mihi tēnei ki te marae o Kuratini, te whare whakaruruhau mō tōku reo, ki te whānau o Kōkiri Ngātahi, o Te Rau Puawai, o MAI ki Pōneke hoki. Nei rā te mihi ki a koutou e whakamāhorahora ana ki au.

Kei te mihi, kei te mihi.

$\mathrm{Ki}$ ōku hoa ako ki runga i te waka o te rōpū puoro whakaora.

He mihi tēnei ki a koutou e tuku ana i tō aroha ki ngā tāngata whaiora.

Kei te mihi, kei te mihi.

Ki tōku whānau kei Maungatautari, kei Tāmaki Makaurau.

Ahakoa he roa te wā kei waenganui i a tātou, ka nui te aroha nō koutou i rongo ai ahau. He mihi pounamu ki a koutou e poipoi nei i ahau.

E mihi ana, e mihi ana.

Ko wai au nāku tēnei i tuhi?

Ko Mātaatua te waka

Ko Tūhoe rātou ko Ngāti Awa, ko Airihi, ko Kōtarani, ko Ingarani, ko Tieke, ko

Tiamana ngā iwi.

Ko Te Whare o Toroa te marae.

Ko Putauaki te maunga.

Ko Ōhinemataroa te awa.

Ko Wharepaia te hapū.

Kei te noho au ki Taone Hou, ki Te Whanganui-a-Tara.

Ko Nolan Hodgson tōku ingoa. 
This mihimihi acknowledges all those who are part of this research, all of the teachers, supervisors and friends who have influenced its development or provided experiences that I have learned from. I am particularly grateful to all the young people who I had the pleasure of practising music therapy with as these experiences provided the raw ingredients for this project.

As always, my family have constantly encouraged me to follow my passions and I cannot express how much their support means to me. Most importantly, this dissertation is dedicated to my grandma, Betty Hodgson, who passed away as this work was nearing completion.

It is through her that I trace my Māori heritage and connection to my Tūhoe and Ngāti Awa iwi (tribes). These iwi are acknowledged at the end of my mihimihi along with my ancestors from Ireland, Scotland, England, Czech Republic and Germany. I identify with Mount Edgecumbe and the Whakatāne river through Wharepaia, which is the name of my hapū (sub-tribe/clan). Our meeting house is named Te Whare o Toroa and our ancestors arrived in Aotearoa on the Mātaatua canoe. Currently I reside in Newtown, Wellington and my name is Nolan Hodgson. This is my identity.

\section{Ethics Statement}

This project received ethical approval by the Massey University Human Ethics Committee:

HEC: Southern A Application - 11/41.

NZSM Master of Music Therapy Programme ethical template for student research in NZSM 526 undertaken as observational studies, theoretical or case study research. 


\section{Chapter 1 Introduction}

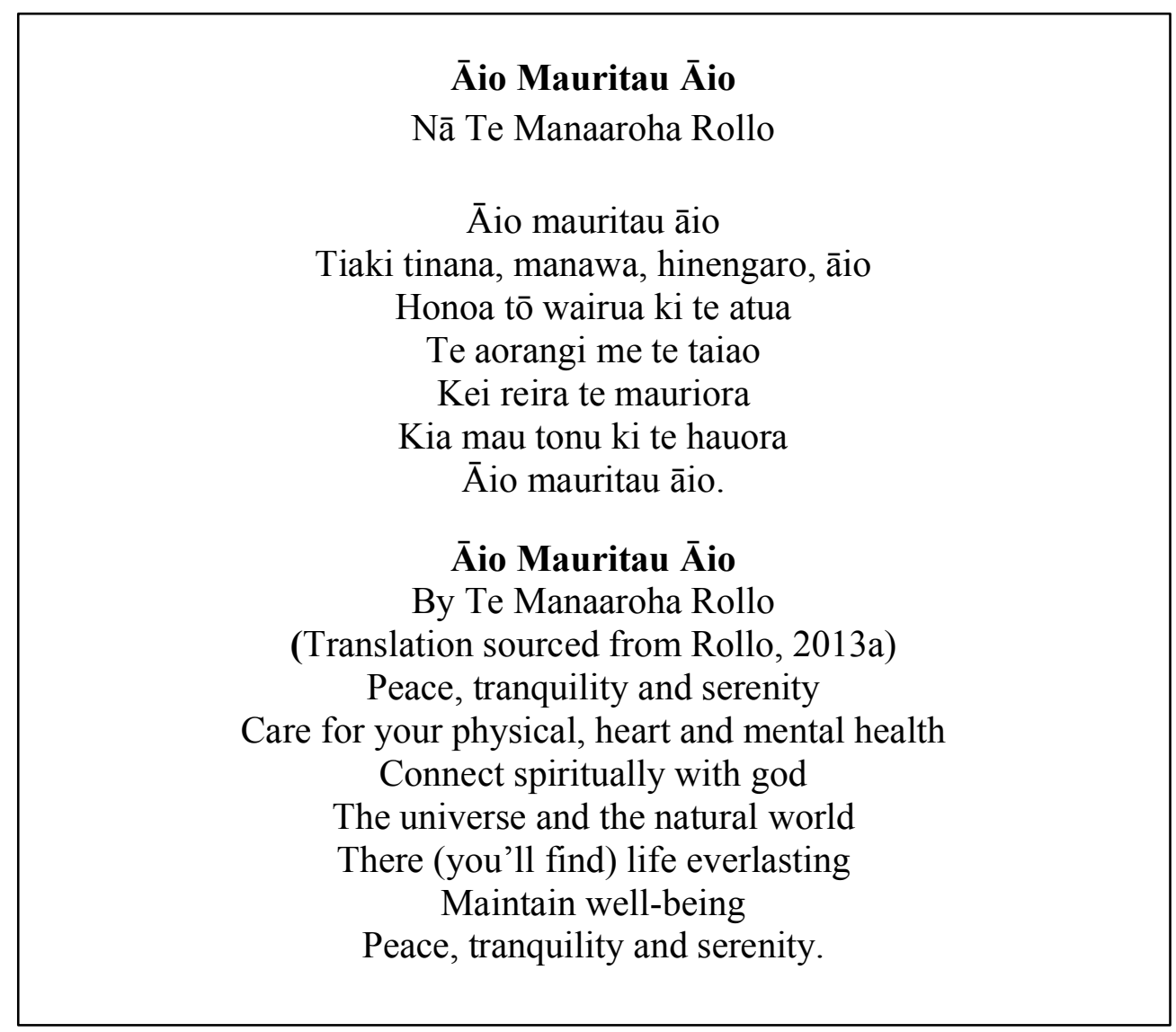

This waiata (song) was gifted by Te Manaaroha Rollo to Music Therapy New Zealand and Te Kōkī New Zealand School of Music during a conference presentation entitled "Mā Te Wai - Ka Piki Ake Te Hauora" (2013a). During this presentation the entire audience stood together and Rollo confidently led us through this waiata, explaining that we could use it to care for and nurture our own wairua (spirit) while working as music therapists. Rollo's singing complemented her assured guitar playing very naturally. This created a captivating and engaging environment that enabled the wairua of this waiata to resonate throughout the audience. Its soothing presence effortlessly permeated the atmosphere and brought us all together as a whānau as we sang in unison. The melody supported the message inherent in the lyrics by ascending when encouraging us to connect and engage with the spiritual realm before descending back down to the physical world and natural environment. 
As an audience member, I felt this waiata conveyed an essential feeling of peace, awareness and kotahitanga (unity), exemplified in the title phrase $\bar{A} i \bar{o}^{1}$. It brought all of us together in that moment to appreciate and acknowledge the importance of nurturing our wairua, tinana, hinengaro and manawa. These sentiments were both expressed and experienced within the performance of this waiata as it served to sustain and support our physical, mental and spiritual well-being.

This waiata embraces music as a means to enhance or sustain our well-being in a way that reflects our understanding of music within music therapy. Hearing Rollo speak at this conference cemented my ambition to pursue this avenue of research and further investigate the relationship between hauora (health/well-being) and music therapy. My interest in this relationship has grown as my knowledge of the ways my own tupuna (ancestors) conceived of well-being has developed and my experience with music therapy has increased.

The links between these two worlds were thrown into sharp relief three years ago when my kaiako (teacher) shared a model of wairua called 'Te Tuakiri o te Tangata' (Mataira, 2000) $)^{2}$ with our te reo Māori (Māori language) class. In trying to understand and relate to different concepts within this model, I immediately began drawing on my experiences within music therapy. While I was incredibly excited and stimulated by this experience, I found it difficult to share this with others as this model is

\footnotetext{
${ }^{1}$ This phrase was popularised in the karakia 'Āiō ki te Aorangi' composed by Rose Pere and used to introduce her book outlining her model of health, Te Wheke (1991).

${ }^{2}$ This model was developed by Dame Kāterina Te Heikōkō Mataira, a respected Maori intellectual, language proponent, educator, artist and writer. Along with Ngoi Pēwhairangi, she co-founded Te Ataarangi, the community based Māori language education programme that I attend.
} 
conveyed entirely in te reo Māori and embedded within mātauranga Māori (Māori epistemology). While my fluency in te reo Māori and understanding of this model has increased since then, I am fully aware that any attempt to translate it into English would corrupt or disrupt its authentic meaning.

Therefore, this research has been conducted to begin bridging this gap and explore how we can further develop the relationship between these two areas in a way that is mutually understandable and remains true to Māori principles and concepts. Because 'Te Tuakiri o te Tangata' requires a significant amount of familiarity with mātauranga Māori to appreciate and understand correctly, I have chosen to exclude it from this project. However, I must acknowledge that it significantly influenced my understanding of health/well-being and I have continued to pursue a greater depth and breadth of understanding of the concepts it describes.

To enable the development and continuation of discourse reflecting on parallels between hauora Māori and music therapy, contemporary Māori models of health were examined. From this, contemporary ecological models of music therapy were discussed to explore how they may be analogous to Māori understandings of health. Techniques developed within grounded theory (Charmaz, 2014) were used for the secondary analysis of data drawn from my clinical practice. Categories relating to kaupapa Māori ${ }^{3}$ health models were identified within this data and discussed in relationship to music therapy theory and praxis. The practical component of this project was undertaken within an acute mental health unit that will be described in full below.

\footnotetext{
${ }^{3}$ The term 'kaupapa Māori' refers to perspectives or philosophies derived from a fundamentally Māori epistemology (Pihama, 2001).
} 


\subsection{The Setting}

This research took place within an acute mental health unit for adolescents operating within a bicultural model of healthcare and emphasising Māori approaches to health and well-being. Situated within a local hospital, the unit has facilities to accommodate 13 rangatahi (youth/young persons) aged 13-18 and up to eight further rangatahi may also attend the therapeutic day programme. Within the unit, Durie's Te Whare Tapa Wha $\bar{a}$ (1998) model of health was used as an assessment framework, allowing me to gain a practical understanding of this model as it is employed within a contemporary mental health setting. This model will be described in detail in the literature review that follows.

As a student music therapist on placement within this unit, I ran group and individual music therapy sessions and coordinated my work to complement that of the wider multidisciplinary team. I also attended other therapeutic groups, working alongside occupational therapists, nurses, kaumātua (elders), support workers, psychologists, psychiatrists, school teachers, and other specialist support workers. I received referrals for music therapy from many of these different staff members and was able to consult any of them if I had any questions relating to their particular specialisation. This greatly enhanced the development of my practice and familiarity with the clinical milieu surrounding each rangatahi.

To ensure my sessions complemented the work of all these other professionals I regularly attended multidisciplinary team meetings and consulted patient files. My music sessions aimed to engage the rangatahi in musical activities such as group singing, playing instruments, improvising and composing original or adapting popular songs. Therapeutic goals underpinned the choice and nature of these activities and 
generally focused on enabling and encouraging the rangatahi to express themselves, interact positively with others, assert their identity and individuality and develop confidence in themselves. To communicate relevant aspects of this practice with the wider team I regularly contributed to progress notes kept by the unit relating to each rangatahi. Other staff also regularly attended my group sessions and witnessed or heard much of the work I undertook with individuals. This ensured these staff members gained an understanding of my practice so they could better support me and appreciate how my practice fitted alongside that of the rest of the team. I will now provide a brief overview of literature relating to the use of music therapy with adolescents in mental health contexts to describe how this informed my therapeutic approach within this setting.

\subsection{Music Therapy with Adolescents in Mental Health Contexts}

A meta-analysis examining the use of music therapy with children and adolescents with psychopathology was conducted by Gold, Voracek \& Wigram (2004). This concluded that music therapy is an effective therapeutic intervention in this setting and recommended an eclectic approach. This approach allows practitioners to draw on a range of different theories and models of music therapy so they can remain open and flexible to accommodate the unique needs of individuals receiving therapy.

This recommendation is supported by McFerran (2010) who encourages practitioners to remain aware of their own theoretical orientation and stance. This ensures therapists present themselves genuinely and authentically when working with adolescents. She qualifies this by acknowledging that this stance may change moment by moment within a music therapy session or when working with different people. McFerran also delineates different anticipated outcomes possible when employing a 
psychodynamic, humanistic, behavioural or ecological approach. These are, respectively, resilience, identity formation, competence and connectedness. In relation to this project, the benefits of adopting an eclectic approach is supported as these four outcomes are all potentially valuable within this mental health setting.

Like McFerran, Cobbett (2009) also encourages an open and flexible therapeutic stance, similar to an eclectic approach and contends that boundaries should be created collaboratively with the young people involved. Cobbett asserts that it is useful to incorporate unique aspects of adolescent culture when working with young people. He discusses the use of computer generated music and rap within his own practice and argues that adolescents are more comfortable within therapy involving familiar styles of music such as these. McFerran (2010) also advocates for the use of familiar, popular songs in sing-a-longs or for adaptation as well as activities involving original compositions and improvisations.

The use of improvisation with adolescents in psychodynamic oriented music therapy is explored by Tervo (2001) who focuses particularly on the use of rock music. He suggests adolescents use this style of music to connect with their emotions and outlines three stages of adolescent music therapy: The initial stage of interest, the stage of learning and finally the stage of improvisation. This latter stage is achieved through a trusting adolescent-therapist relationship where the adolescents are confident to express themselves freely and creatively. This can also be described as the 'potential space"4 where a process of change can occur within the adolescent. However, Tervo articulates how music can act as a 'transitional object' in which

\footnotetext{
${ }^{4}$ The concepts of 'potential space' and 'transitional object' mentioned here are adapted for music therapy and based on the psychoanalytical work of Donald Winnicott (1991) relating to play and a true sense of self.
} 
adolescents can invest and creatively explore their fantasies using music. This then enables growth and development through healthy expression of an internal conflict.

This value of creativity and self-expression is examined by Sausser \& Waller (2006) who concluded that music therapy enhances independence, self-esteem, coordination, motor skills and socialisation. Music is described as a motivator and reinforcer that can be utilised creatively to assist young people as they grow biosocially, cognitively and psychosocially. Further, they iterate the need to plan and structure music therapy interventions based on individual or group needs and preferably in tandem with an interdisciplinary team.

Weaving these publications together, I maintained an eclectic approach within my practice in order to encourage acceptance while remaining flexible to meet the specific needs of individual rangatahi. Boundaries were developed in concert with rangatahi and methods involved the use of familiar songs along with composition and improvisation. Due to the dynamic nature of our unit and the fluctuating state of many of the rangatahi it was very difficult to plan and prepare for both group and individual sessions. Instead, a broad range of techniques, activities and musical material was prepared and then drawn upon or adapted situationally. There was however some longer term work in which careful planning and consideration of appropriate musical activities was conducted. This will be discussed in the clinical vignette in chapter five. The following chapter (chapter two) provides an overview of literature relating to the research question, 'How do kaupapa Māori models of health relate to my practice as a music therapy student in a specialist unit at a local hospital for young people experiencing acute mental health problems?' 
This overview begins by outlining disparities in mental health outcomes experienced by Indigenous peoples internationally and by Māori in Aotearoa, followed by a brief outline of public health policy aimed at redressing this. This analysis is necessary, as it articulates the rationale for undertaking this study by providing a critical analysis of the conditions that generated these disparities, to inform an appropriate response.

The implications of this for music therapy in Aotearoa are acknowledged and the literature concerning both kaupapa Māori understandings of health and music therapy is summarised. The concept of hauora (health/well-being) is then explored and expanded upon by describing Te Whare Tapa Whà (Durie, 1998) and Te Wheke (Pere, 1991), which are the two kaupapa Māori models of health that this project focuses upon. Links are drawn with the work of the indigenous scholar and music therapist Carolyn Kenny and the relationship between music therapy and traditional healing practices and the development of ecological perspectives in music therapy are outlined.

Chapter three describes the kaupapa Māori research approach employed throughout this project and defines this theoretical stance in relation to the principles of indigenous research as outlined by Smith (2012) and Wilson (2008). An overview of the grounded theory methods used during the data analysis process are then given and the method of secondary data analysis described before outlining ethical considerations relating to this project.

Findings are described throughout chapter Four which is split into four sections relating to the four dimensions of health within Te Whare Tapa Whä. Codes and categories developed through the process of data analysis are illustrated in four 
different diagrams relating to these dimensions and examples from the data supporting these are given.

Chapter five consists of a clinical vignette describing the practice of music therapy with one individual in detail. This provides a richer description of the findings by demonstrating how the practice relates to the categories and codes used. This leads to the final discussion (chapter 6) that examines links between the kaupapa Māori health models examined and music therapy. This discussion focuses on findings drawn from chapter four and also examines links with ecological perspectives of music therapy. The following chapter provides an overview of literature relating to the research question, 'How do kaupapa Māori models of health relate to my practice as a music therapy student in a specialist unit at a local hospital for young people experiencing acute mental health problems?' 


\section{Chapter 2 Literature Review}

The focus of this project is situated at the interface between music therapy and kaupapa Māori approaches to health and well-being. This review will explore literature inquiring into the links between these ${ }^{5}$. An overview of Māori understandings of health and models representing this will then be addressed before examining recent literature discussing ecological theories of music therapy. Firstly however, motivations for this study are elaborated upon in reference to current health policies within Aotearoa (New Zealand) and the poor relative health outcomes of indigenous peoples worldwide.

\subsection{Indigenous Mental Health}

Internationally, the health of indigenous communities has been compared to the worlds' very poorest (Stephens, Porter, Nettleton, \& Willis, 2006). Disparities in mental health between indigenous peoples and the general population have been identified by the World Health Organisation (WHO, 1999) throughout the Americas, the Pacific, Australia, Russia, Taiwan and New Zealand. This WHO report concluded that historical trauma and the continued oppression of indigenous peoples put them at greater risk of developing mental illness and stressed the importance of acknowledging how social, political and environmental factors continue to influence the mental health of indigenous communities.

These underlying causes were examined by King, Smith \& Gracey (2009) who argued that the continued marginalisation of indigenous peoples and the disjunct between

\footnotetext{
${ }^{5}$ Commensurate with the grounded theory methodologies employed in this research, this literature review was updated as themes and ideas emerged during data analysis and the description of findings.
} 
their holistic perspectives of well-being and mainstream medical approaches to healthcare exasperate the poor health status of indigenous peoples. A review of the literature measuring the mental health of indigenous young people from 1998-2008 (Williamson et al., 2014) noted that this population is disproportionately exposed to risk factors that can lead to mental health related harm and identified this as a critical issue in New Zealand, Australia, Canada and the US.

In Aotearoa, disparities in mental health have been noted by a range of authors (Durie, 1997, 2001, 2008; Baxter, 2005, 2008; Kingi, 2007) and recorded through measures such as the Youth2000 survey series (Crengle et al., 2013) and Te Rau Hinengaro NZ Mental Health Survey (Oakley Browne, Wells \& Scott, 2006). Both of these publications identified disparities between Māori and non-Māori with Crengle et al. noting that these continued to persist from surveys undertaken over ten years previously. Similarly, Te Rau Hinengaro NZ Mental Health Survey examined the prevalence of mental health disorders, patterns of onset and access to services in New Zealand. This identified that Māori and Pacific peoples had a higher prevalence of mental health disorders, were less likely to access mental health services and that these trends were still evident after taking into account sociodemographic differences between populations.

\subsection{Policy Responses in Aotearoa}

These disparities are addressed in Te Puāwaiwhero: The second Māori mental health and addiction national strategic framework 2008-2015 (Ministry of Health, 2008). This report acknowledges the link between culture and well-being and outlines a broad range of initiatives intended to increase Māori participation within the mental health workforce, increase the range of specialist services and the responsiveness of 
mainstream health service providers to Māori. It also identifies the pivotal role that research will play in contributing to the achievement of these goals by measuring progress, developing kaupapa Māori models of practice and enhancing the capabilities of Māori researchers.

These goals are supported by the reports Improving the Transition: Reducing Social and Psychological Morbidity During Adolescence (Gluckman, 2011) and Te Tāhuhu - Improving Mental Health 2005-2015 (Minister of Health, 2005). These stress the importance of involving Māori in the development of services targeted at addressing health disparities with non-Māori and ensuring these are justified by evidence based research.

These initiatives were supported by He Korowai Oranga (Minister of Health and Associate Minister of Health, 2002). This established a framework for public policy in Aotearoa that actively acknowledged values important to Māori. These supported holistic approaches to health and Māori involvement with and control over the direction and shape of initiatives developed to support the well-being of Māori. In line with the Treaty of Waitangi, the principle of rangatiratanga (right to exercise authority) was embedded as a key thread within this framework.

This notion is supported by prominent Māori health academics Mason Durie (1997, 1998, 2007) and Te Kani Kingi (2007) who both acknowledge that the Treaty of Waitangi secures the right of access to culturally responsive health services. Durie (1997) also notes this is enshrined within the draft United Nations Declaration on the rights of Indigenous Peoples ${ }^{6}$. The WHO (1999) also highlighted the need to develop programmes of intervention and prevention that avoid narrow psychotherapeutic or

\footnotetext{
${ }^{6}$ New Zealand endorsed the final version of this Declaration in 2010.
} 
psychopharmacological approaches. Instead they encouraged incorporating local beliefs and approaches to health and well-being in order to make these programmes effective.

\subsection{Music Therapy and Hauora Māori}

As music therapy is practised as a health intervention within Aotearoa, it is therefore necessary that it is able to accommodate Māori understandings of health and practices that maintain well-being. This provides the rationale for undertaking this research project. The prevalence of mental health issues within Māori communities indicates that there is a need for culturally responsive interventions in this field. This is reflected in government policy encouraging the development of these capacities within the health system.

In pursuit of developing this capacity, early writing exploring the connections between music therapy and kaupapa Māori approaches to health and well-being began with McIvor (1988). She described many different forms of waiata, their different purposes and the significant role of karakia (incantations) in all facets of traditional Māori life. She ascribes the therapeutic significance of these traditional uses to their capacity to enshrine and communicate cultural values within communities. Their ability to enhance group solidarity, identity and self worth, encourage emotional release and support physical, mental and spiritual well-being is acknowledged as a useful support for contemporary therapeutic practice. Croxson (1989) refers to McIvor's article and supports the idea that an awareness of Māori values is crucial for music therapists in Aotearoa. She also introduces the four cornerstones of Māori health, based on Durie's Te Whare Tapa Wha (1998) and notes the intrinsic relationship music maintains within and between each of these dimensions. 
Following on from this, Georgina Kirby (1990) of the Māori Women's Welfare League reiterates the importance of waiata and music within Māori communities. These provide guidance, handed down from tupuna (ancestors), that shape attitudes, inform social interactions and offer frameworks for understanding of phenomena. Examples of waiata are also given by Kirby to illustrate their role in the promotion and maintenance of health. Similarly, Katene (1991) acknowledges the myriad social functions of waiata within traditional Māori society. He highlights their particular significance as a means of transferring knowledge and commemorating significant people and events. Katene also focuses on the crucial role waiata play in expressing emotional experiences and their ability to reshape or revitalise individuals experiencing hardship or pain.

The use of taonga puoro (traditional musical instruments) by Māori is articulated by Nunns (1995) who laments that much of the knowledge surrounding their use was lost yet maintains their use in healing contexts was significant. Nunns disputes 19th century colonial discourse that relegated them to the role of mere entertainment or recreation. Instead he asserts that their primary concern was associated with the wairua (spirit) and connecting with the spiritual realm.

Later writing by McIvor (1998) begins by acknowledging traditional Māori uses of waiata to provide a link with the spiritual realm and assist in the healing process. She then describes a project involving Māori participants in a process of guided imagery and music. McIvor comments that principles underpinning this form of therapy appear compatible with holistic Māori views of health and well-being.

In an interview conducted by Elwafi (2008) Tina Fraser also supports a holistic Māori understanding of health. She comments that Māori are particularly affected by social 
determinants of health as well as their interaction with the environment. The performing arts (including music and dance) are explained as being primarily spiritual, often expressing genealogical links with whānau (family), whenua (land) and atua (deities). Fraser describes the philosophy of traditional Māori healing practices as focusing on balance and asserts that this philosophy is embedded in te reo Māori (the Māori language) and the environment.

The significance of the environment is also acknowledged by Rollo (2013b) in relation to rongoā (traditional medicines/remedies) which are sourced from local flora. The role of these rongoā, as well as waiata, karakia and mirimiri (massage) in Māori health practices is explained by Rollo, describing how these were traditionally used by tohunga (experts/priests) to heal specific illnesses or promote hauora (health/vigour). Rollo describes the use of waiata and karakia as traditional forms of music therapy. She then details how they are being used within contemporary healthcare settings before establishing a link with contemporary music therapy practice through the Raukatauri music therapy centre.

An extended exploration of the link between contemporary music therapy and Māori perspectives of health is undertaken by Dennis Kahui (2008). In this research, Kahui describes how he approached his own music therapy practice with a Māori perspective to ensure it was culturally appropriate for Māori. He did this by utilising Māori musical concepts within his practice involving youth aged 14-19 years being treated for acute psychological symptoms. He stressed that the consultation of Kaumātua was essential regarding the use of Māori music and protocols within music therapy. Kahui also commented that there were potential benefits for tauiwi (nonMāori) youth involved in Māori musical activities. Positive psychological effects were observed following their inclusion and participation within the community 
during these activities. He noted the suitability of Te Whare Tapa Whā as a music therapy assessment tool and that the use of a Māori approach assisted in facilitating the achievement of therapeutic goals for young Māori.

This overview of the literature concerning links between Māori understandings of health and the practice of music therapy demonstrates that there has been a sustained interest in this topic as music therapy has developed within Aotearoa. The majority of authors have sought to explain the significance and many practical applications of music within Māori communities, including its recognised capacity for healing. McIvor and Kahui have been instrumental in actively investigating links between music therapy and Māori understandings of health.

The common thread linking all of this writing together however is the description of the many ways music is used by Māori to support and sustain health. A particular emphasis is placed on wairua and the importance of spiritually connecting with atua (deities), whenua (land), tupuna (ancestors) and whānau (kinship groups/communities) through karakia and waiata. These practices establish a clear connection between music and the maintenance of health. The following section will explore this process further by examining contemporary Māori models of health.

\subsection{Hauora Māori}

The term hauora is commonly translated as 'health', yet for Māori the values underpinning the concept of health differ significantly from a western medical understanding. Wenn (2006) investigates this concept and identifies values underpinning the term 'hauora' which all stem from an intrinsically Māori worldview. She refers to Royal (2002) and stresses the importance of situating this worldview within a framework based upon Māori cosmogony. 
This importance is demonstrated by Kirby (1990), Katene (1991) and Rollo (2013b), all of whom established the cosmogonol foundations of the Māori concepts they described in relation to music therapy. The concept of music is securely embedded within a Māori cosmogony through this quotation from 1849 by Matiaha Tiramorehu, referring to the beginning of creation itself: "Kei a te pō te timatatanga o te waiatatanga mai a te atua. Ko te ao, ko te ao mārama, ko te ao tūroa" (Rollo, 2013b). This is translated by Hirini Melbourne as "It was in the night that the Gods sang the world into existence, from the world of light, into the world of music" (Melbourne, Nunns \& Yates-Smith, 2003). Similarly, The concept of hauora is embedded within the story of creation in the following whakapapa (genealogy, lineage) given by Rev. Māori Marsden (2003). 


\section{Figure 1: Whakapapa of Creation, Marsden (2003).}

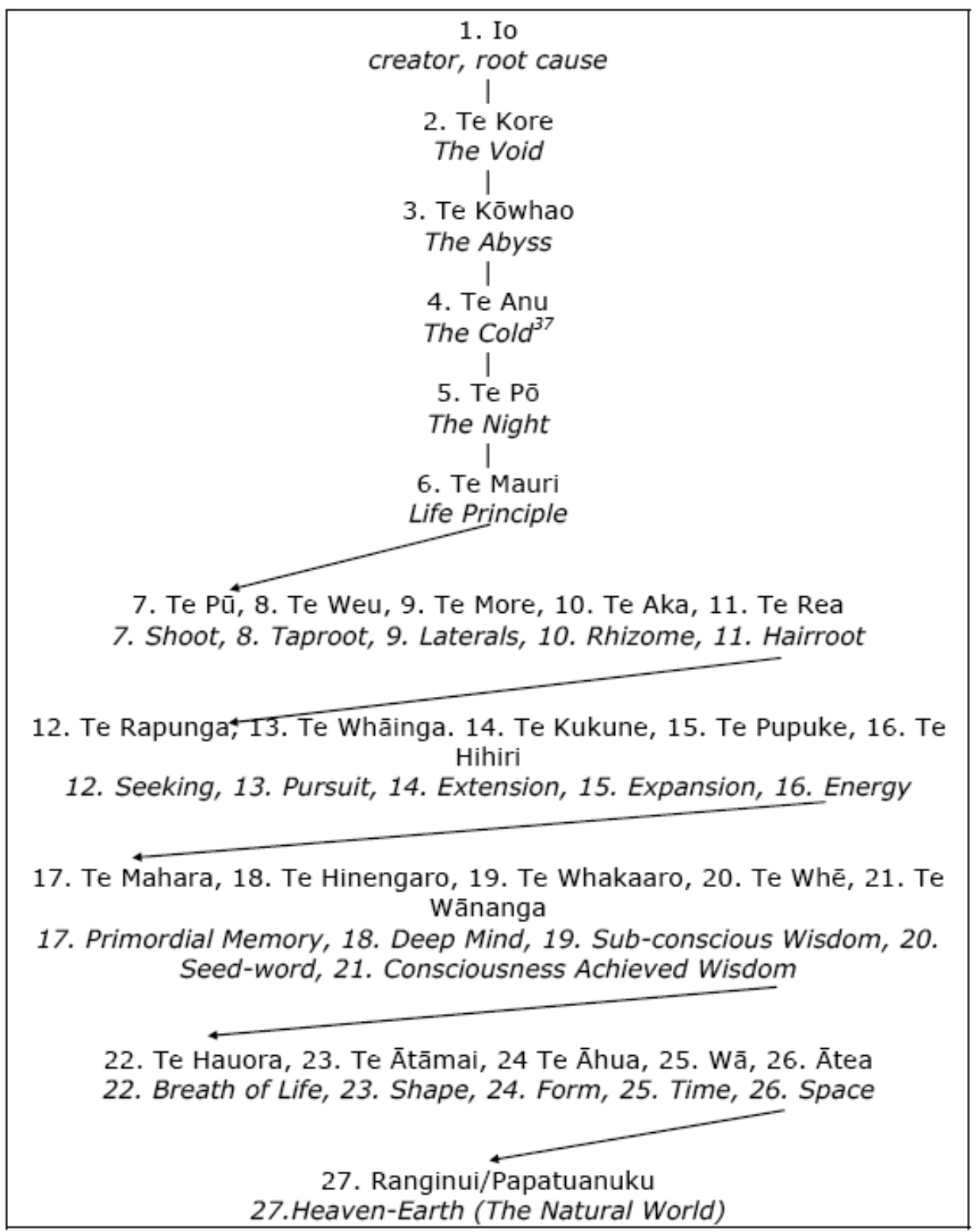

While the cosmogonol foundations of hauora are made clear through this whakapapa, there is tension surrounding contemporary use and understanding of the term. Heaton (2011) examined this, observing that its use within curricula documents decontextualises and over-simplifies the term. She suggested that this reinforces dominant, hegemonic discourses and fails to articulate the concept of hauora in a manner consistent with Māori understandings. According to Kiro et al. (2004) hauora 
was understood differently by rangatahi (youth) and kaumātua (elders) suggesting that the understanding of this term is not static.

Within her doctorate research focusing on hauora, Wenn (2006) consulted with a group of kaumātua (elders) to develop a range of values underpinning the concept. She identified that hauora differs from a western conception of health in that it is holistic and focuses on well-being rather than situating individuals on a health-illness

continuum. Wenn then conducted an analysis of three contemporary Māori models of health in relation to the value bases that she developed with her kaumātua. The models examined were Te Whare Tapa Whā (Durie, 1998), Te Wheke (Pere, 1991) and Ngā Pou Mana, which was developed by the Royal Commission on Social Policy in 1988 and is commonly attributed to Manuka Henare (Wenn, 2006).

Ngā Pou Mana was designed primarily as a model for social development and consequently has not been applied as often within health settings as Te Wheke and Te Whare Tapa Whā (Wenn, 2006). This literature review will therefore focus on Te Whare Tapa Wha and Te Wheke as these are the models most commonly employed by health professionals in Aotearoa (Wenn, 2006).

\subsection{Te Whare Tapa Whā}

Te Whare Tapa Whä is a model of health or well-being that began to take shape in 1982 at a Māori Women's Welfare League hui (gathering/meeting) for fieldworkers in a research project (Durie, 1998). Sir Mason Durie attended this hui and later developed and described the model which conceives of health as an interaction of four dimensions: taha wairua (the spiritual side), taha hinengaro (thoughts and feelings), taha tinana (the physical side) and taha whānau (family). According to Durie (1998), this model was developed due to concerns that contemporary psychosomatic 
constructions measured a person's health only according to their mental and physical states and ignored the many social and cultural factors which impact upon a person's well-being.

This holistic conception of health ensures that other aspects of a person's lifestyle are acknowledged as determinants of health, including those that are culturally very significant. For Māori, these might include a relationship with the environment or a collective understanding of identity. While the model is split into four dimensions, they are represented as walls of a whare (house) (Figure/Illustration) to illustrate their interdependence. An effect on any one of these dimensions will have consequences that impact the other three and a state of equilibrium reflects an optimal state of health. Brief explanations of these four concepts will now be given, beginning with te taha wairua.

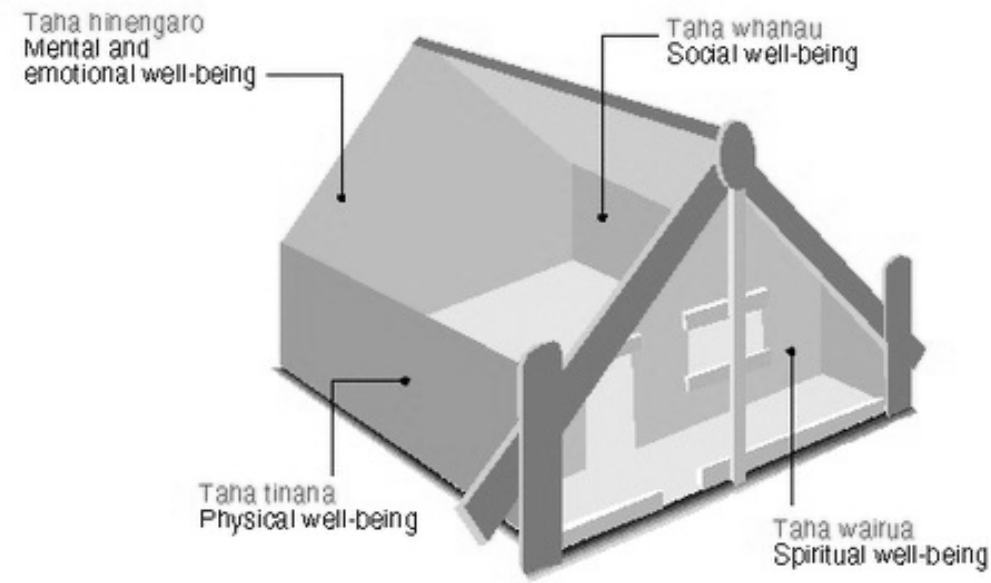

Figure 2: Te Whare Tapa Whä $\bar{a}^{7}$

\footnotetext{
${ }^{7}$ Image sourced from: http://health.tki.org.nz/Teaching-in-HPE/Curriculumstatement/Underlying-concepts/Well-being-hauora
} 


\subsubsection{Te Taha Wairua}

While it is generally translated as the intangible spirit or soul of a person, Wairua incorporates many different elements and is regarded as the most essential component for health for Māori (Durie, 1985; Love, 2004). Described as the capacity for faith and an understanding of the relationship we maintain with the environment and our unique heritage (Durie, 1998), Wairua also incorporates experiences of mutually rewarding encounters between people and the maintenance of cultural integrity (Durie \& Kingi, 1997). The mauri (spirit/vitality/life force) and a sense of spiritual awareness are central to Māori identity and if these are diminished an individual can become more prone to illness (Durie, 1998).

\subsubsection{Te Taha Hinengaro}

The capacity to think, to feel and express or communicate thoughts and emotions comprises the hinengaro dimension (Durie, 1998). Associated with psychological or behavioural qualities (Durie \& Kingi, 1997), taha hinengaro encourages an integrative, holistic understanding of thoughts and feelings and acknowledges that they originate from the same source within the individual. Non-verbal communication of emotions through gesture, facial expression or more overt actions such as crying is valued equally alongside verbal communications. This is particularly relevant to mental health practitioners seeking verbal expressions of emotional experience as words may be regarded as superfluous or even demeaning in some situations (Durie, 1998).

\subsubsection{Te Taha Tinana}

This is the physical dimension of health, including the capacity for physical growth and development. Physical manifestations of illness may reflect stress or deterioration 
within the other three dimensions. Our physical self is intrinsically connected to our spiritual self and enables us to engage in activities that support our spiritual, mental and emotional health as well as interact with our family and communities that we belong to.

\subsubsection{Te Taha Whānau}

This dimension acknowledges the significance of the family and other communities or social networks that impact upon an individual's well-being. Whānau are acknowledged as the primary support system for individuals and an individual's illness can be regarded as a reflection of the whānau as a whole (Durie, 1998). A person's identity is also affected and defined by the relationships that they maintain and these relationships influence their mental, emotional and physical health.

\subsection{Te Wheke}

This model was developed by Dr. Rangimarie Turuki Pere and first presented at the 1984 Hui Whakaoranga (Durie, 1998). Since then it has been applied in the areas of health, education and social services training (Love, 2004). Pere (1991) uses the image of Te Wheke (an Octopus) to represent the well-being of an individual or family, with each tentacle symbolising a dimension supporting overall health or wellbeing. The many suckers on each tentacle reflect the various facets within each dimension and the intertwining of the tentacles demonstrate that all dimensions merge and interact. The tentacles must therefore be understood in relation to each other and all serve to provide sustenance to the whole. The head of the octopus represents the individual or family and the eyes reflect the concept of waiora (total well-being). 
The eight values represented by each tentacle will be briefly discussed here ${ }^{8}$ but Love (2001) cautions readers that intricacies of meaning and understanding are lost in translation. Pere (1991) acknowledges that her knowledge of these terms is informed by her learned forbears from Ngāti Ruapani, Tūhoe Pōtiki and Ngāti Kahungu who received insight over a period of twelve thousand years.

\subsubsection{Mauri}

(Life Principle, Thymos, Psyche)

Mauri is regarded as an elemental energy that serves to bind the physical and spiritual realms. A person's mauri begins with the first breath ${ }^{9}$ and ends when a person dies and their spirit leaves their physical self. Everything has mauri and in this way all things are regarded as having the same divine right to existence. Birds, trees, rivers, buildings and mountains all have a unique mauri that should be respected and must be taken care of. If a river becomes polluted or a building damaged by water then its mauri diminishes. Songs also have a mauri such as that which is carried by the rhythm and melody. This can be affected negatively if a person loses their place in a song or positively enhanced with additional instruments or harmonies. Similarly, Pere describes how a child's mauri waxes when they feel respected and accepted within their whānau or wanes when they are chastened or neglected.

\subsubsection{Mana}

(Divine Right, Influence, Prestige)

\footnotetext{
${ }^{8}$ Pere has described more than eight values in different iterations of Te Wheke. These eight are the most commonly referred to within health settings (Wenn, 2006)

${ }^{9}$ The creation of the mauri is referred to in the phrase 'Tihei mauri ora', an invocation of life commonly heard at the end of karakia.
} 
Pere states that the concept of mana is " beyond translation from the Māori language" (1991, p.14). It is multi-dimensional and commonly translated as authority or charisma but it is important to recognise that the nature of mana is relational. Mana can be enhanced or diminished through nurturing or neglecting relationships with others, with the environment or with the spiritual realm. The dimension of mana that Pere focuses on is mana ātua (divine right) which everyone possesses and which recognises the absolute uniqueness of the individual.

\subsubsection{Wairua}

(Spiritual dimension)

Wairua is described as the spirit and within that our connection to the divine creator ĀĪŌ Mātua (God/Goddess the divine parents). Pere acknowledges Papatūānuku (the earth mother) as the natural place of communion with ĀIIŌ Mātua and te reo Māori (Māori language) as the language emanating from and connecting us to this spiritual realm.

\subsubsection{Taha Tinana}

(Physical dimension)

This relates to physical exercise and recreation that encourages the development of other dimensions of health. Through physical games and exercises we develop balance, agility, rhythm, coordination, stamina and experience the sheer joy of being human. Taha tinana also recognises that we must maintain a healthy diet and seek adequate shelter for our physical selves.

\subsubsection{Whanaungatanga}

(Kinship ties - Extended families across the universe) 
This aspect acknowledges our connections with others, particularly our whānau and tupuna, that give us a sense of belonging and security in our identity. The health and well-being of the individual and the group are one and the same and activities that benefit the collective are valued over independent success or individual fortune.

\subsubsection{Hā a koro mā, a kui mā}

(Breath of life from forbears)

'Hā' literally translates as breath while 'a koro mā, a kui mā' means 'of grandfathers, of grandmothers'. This acknowledges every individual's unique heritage and identity. These traits are communicated through genetics and through interaction between children and their whānau.

\subsubsection{Whatumanawa}

(Relating to the emotions and senses)

This aspect appreciates that there is a time and a place for every emotion and that it is necessary to fully express and experience these emotions. Value is placed on this process as it can be a source of energy for creative activities and pursuits.

\subsubsection{Hinengaro}

(The mind)

This refers to the conscious whole of the mind, including all cognitive processes as well as feeling and intuition. The term 'Hine' (female) and 'ngaro' (hidden) intimate that these internal processes are private. Therefore indirect, metaphorical speech or non-verbal expression are commonly used to communicate these internal thoughts and feelings. 
When articulating the significance of Te Wheke to our health system, Love (2004) concludes that it challenges contemporary theories of psychology and counselling. It contradicts the belief that individuals can conceive of themselves as independent of their history/environment, the notion that all thoughts/feelings can be verbalised and the focus on individual self-esteem and the right to personal choice. Instead, Te Wheke emphasises collectivity, the connection between past/present/future, a spiritual approach to health/well-being and the concept of sustaining interrelated dimensions rather than correcting dysfunction.

Although it is more complex, there are clear parallels between Te Wheke and Te Whare Tapa Whă. Both stipulate that spirituality is the primary concern regarding health. They also strongly advocate a holistic approach in which a range of dimensions or capacities interact to produce an overall picture of health. This perspective will now be examined in relation to music therapy literature, beginning with the work of the Indigenous music therapist Carolyn Kenny.

\subsection{Carolyn Kenny}

As a Professor of Human Development and Indigenous Studies, Carolyn Kenny's music therapy publications have a unique resonance with Māori approaches to wellbeing. Kenny has consistently advocated understandings of music therapy that involve an awareness of spirituality and emphasise our connection with the environment. Her theoretical contributions to music therapy have offered understandings of well-being that reject disjunctive labels such as 'disabled' and continuums of health vs. illness in favour of a holistic or relational approach.

This began with The Mythic Artery: The Magic of Music Therapy, published in 1982 (Kenny, 2006). This publication laments the division of art and science, particularly 
within the dominant medical model of health, which focuses on rectifying identified physical or biological issues while neglecting spiritual dimensions of health. Kenny examines the ability of music to respond to a persons' spiritual needs and posits that music therapy can provide a context for addressing these. She states that music therapy can be a transformative process used as a vehicle for healing by harnessing and expressing a persons' creative potential. This provides a person with spiritual nourishment that assists in rebalancing them and reorienting their place in the world.

Kenny draws upon Indigenous healing practices and rituals involving myths of death and rebirth and asserts that these themes are reflected within patterns of tension and resolution within contemporary music and music therapy practice. The situating of these ideas within traditional knowledge systems parallels the way in which the previously discussed Māori authors highlighted the cosmological foundation of their own writings. Similarly, Kenny focuses on balancing the interplay between dynamic environmental, cultural, psychological, emotional, physical and spiritual aspects of ourselves to maintain our well-being (Kenny, 2002). This corresponds to Te Wheke and Te Whare Tapa Wha with their emphasis on nourishing a range of capacities or values that collectively impact our health.

Kenny suggests that this ecological understanding is the central element connecting her earlier writings to her later development of The Field of Play (2014). First published in 1989, The Field of Play (Kenny, 2006) is a model consisting of seven unique elements or environments that interact to construct our experience of music therapy. These encapsulate the unique modes of being we experience while inhabiting these spaces. 
The two primary fields of the aesthetic and the musical space interact to produce the third primary field that is the field of play. Within this space is the maximum potential for growth and change, including elements that can be traced back to ancient healing systems. These elements are the four secondary fields of ritual, a particular state of consciousness, power and creative process. These seven fields all interact with each other and there is no set order in which they might emerge.

The model is non-hierarchical and the therapist is encouraged to support a participant's development by establishing conditions that foster the establishment of these spaces. As every individual is unique in their aesthetic preferences and ability or comfort within musical activities this model describes principles that underpin the process of music therapy rather than prescribing specific interventions.

\subsection{Music Therapy and Traditional Healing Practices}

Following from Kenny, Aigen (1991) explored the relationship between contemporary music therapy and music's historical healing functions, particularly in shamanistic and ritual contexts. He argued that this was the original function of music and promoted healing through ritual interaction with unseen intrinsic and extrinsic forces. This promoted social and emotional growth and enhanced relationships between the individual, the environment and the broader community.

Aigen also devoted two chapters within his book The study of music therapy: Current issues and concepts (2014) to discussing links between contemporary music therapy and traditional healing practices involving music in non-Western cultures. He acknowledges that the aetiology of illness is fundamentally different in these contexts and that traditional healers occupy a specific cultural role and relationship between 
the spiritual, natural and social environment that is incompatible with a Western epistemology.

Parallels are drawn however between the interest in transpersonal thinking in contemporary music therapy and the role of music in traditional healing practices to mediate between supernatural realms. He argues that psychological concepts such as the id and superego function as a contemporary mythology analogous to understandings of the unconscious mind that refer to spirits or gods. Aigen accepts this is a cultural difference and supports adopting a perspective that is more responsive to the influence of culture within the practice of music therapy.

The Western-centric philosophical base of psychology and psychotherapy is discussed. Aigen insists that the fact that music therapy is treading this same path is not problematic, but the social and political applications of these culturally specific orientations can be. In this respect, Aigen references Chase (2003) who asserts that further research is needed to address and engage with multicultural issues in music therapy.

To conclude these chapters, Aigen notes that the concepts of liminality and communitas ${ }^{10}$ provide a link between contemporary music therapy and traditional healing practices. Liminality is referred to as the state of being during musical activities where participants experince transition from one state to another, a sense of timelessness, the transcending of boundaries or social positions and the state of flow often experienced during improvisation. In turn, communitas describes the sense of unity or camaraderie developed within groups who experience this liminal state together. These notions are described as correspondent to the function of myth and

${ }^{10}$ The terms 'liminality' and 'communitas' are adapted to music therapy by Ruud (1995) from the work of cultural anthropologist Victor Turner. 
ritual in traditional healing practices as methods of effecting change and

transformation within the individual and cohesion within social groups.

\subsection{Ecological Perspectives in Music Therapy}

The development of ecological perspectives within music therapy has since been described by Ansdell (2012), who traced its beginning back to pioneering music therapists Paul Nordoff and Clive Robbins. These two maintained an anthroposophical stance, rooted in the writings of Goethe, and labeled 'creative empiricism' (Robbins, 2005). This progressed to a music-centred approach (Ansdell, 1995) and the development of the term Musicking ${ }^{11}$ which conceives of music as an activity with sociocultural dimensions, an 'ecology' rather than a 'structure' (Ansdell, 2012). This ecological stance is taken up and further developed by Stige in relation to Culture-Centred Music Therapy (2002) and Community Music Therapy (2003). Ansdell then describes the use of ecological models by himself and Pavlicevic to link the theory of communicative musicality with community music theory (Pavlicevic \& Ansdell, 2009; Ansdell \& Pavlicevic, 2005). Finally, Ansdell cites his work with the cultural sociologist Tia DeNora and their respective publications that explicitly articulate an ecological perspective (DeNora, 2013; Ansdell, 2014).

DeNora's book, titled Music asylums: Wellbeing through music in everyday life (2013), supports conceptions of health/wellness that are anti-mechanistic and nonreductionist. She cautions against contemporary shifts towards personalised medicines and the identification of specific 'bio-markers' that signal susceptibility to illness, as this approach implies an aetiology of illness that excludes social, cultural and

\footnotetext{
${ }^{11}$ The term Musicking was developed by Christopher Small (1998) who asserted that music is not a noun, but a verb, the essence of which lies in the relationships established between all participants in a musical performance.
} 
environmental factors. DeNora considers this a materialisation of the concept of illness that absolves the broader community from responsibility for the health of others around them. Instead, DeNora endorses the notion that health/wellness is a phenomenon made up of interrelating dimensions, which are mediated by environment and culture and fluctuate over time ${ }^{12}$.

Subsequently, Ansdell (2014) has articulated how conceptual tools defined by DeNora can relate to music therapy, specifically identifying the concepts of 'musical affordances' and 'musical appropriations'. Musical affordances include everything that a particular musical process or experience offers, dependent on our personal situation. For example, music affords dancing or self-expression but this is regulated by our personal or sociocultural realities. Similarly, musical appropriations describe our unique interactions with a particular musical experience and the ways we actively participate in a musical process. While an orchestral performance may afford dancing, it is unlikely we would appropriate the experience in this way because of the social expectations in a concert house.

Ansdell (2014) also applies these concepts to non-physical phenomena, explaining that music affords clarifying identity, communicating emotion or enhancing personal relationships. He describes how particular features of music can create a personal link with these 'extra-musical' things and adopts the term 'para-musical' to refer to these associated phenomena. This para-musical domain refers to all physical, mental, individual, relational, social or political phenomena associated with musical activities in a specific social, cultural or environmental context (p. 40).

\footnotetext{
${ }^{12}$ This ecological conception of health/wellness is based on a model developed by Freund (qtd. In DeNora 2013, p. 25).
} 
These terms incorporate the unique relationship an individual has with a musical experience at any given moment and acknowledge how this changes in different environments or communities. This is considered an ecological perspective as it specifically acknowledges all the 'para-musical' relationships that inform a person's experience of a piece of music. Ansdell provisionally defines this ecological perspective as "acknowledging musick(ing) as the outcome of the dynamic interdependence of human and "nonhuman" phenomena and resources" (Ansdell, 2012 p. 14).

This approach to music therapy incorporates a much broader view of health than the predominant medical model. It also implies a flexibility that is able to embrace unique cultural understandings of health, the relationship of music with these and also the many different forms or functions of music within different contexts. The relationship between this approach and the kaupapa Māori models of health described earlier will be discussed in chapter six. 


\section{Chapter 3 Methodology}

\subsection{Theoretical Stance}

As a kaupapa Māori research project, the theoretical stance of this enquiry is heavily informed by the work of Linda Smith (2012), Graham Smith (2012), Pihama (2001), Mead (2003) and the published proceedings of two hui focused on kaupapa Māori research praxis (Mikaere \& Hutchings, 2013; Hutchings, Potter \& Taupo, 2012)

The overarching framework in this study will be an indigenous research paradigm, informed by Laycock, Walker, Harrison and Brands (2011), and based on the work of Shawn Wilson as is iterated in his book Research is ceremony, indigenous research methods (2008).

This paradigm maintains an epistemological standpoint that describes the creation of knowledge as a relational process that occurs between the researcher or participants and the environment they are in. To link this with the field of music therapy, the writings of music therapist Even Ruud will also be taken into account. Within his book Music therapy: A perspective from the humanities, Ruud describes the "relational turn" (2010, p. 21) within psychotherapy and developmental psychology and how this informed the theory and practice of music therapy. Ruud posits that our experiences and understandings of phenomena are constructed relationally and holds that this requires an interpretivist stance that is inherently reflexive. This requires us as researchers to remain cognisant of the ways in which our own culture, belief systems or preferred discourses impact our inquiry by affecting the way we relate to people, environments and even ideas we may encounter. 
Returning to Wilson (2008), the ontological position he defines allows for multiple realities to exist, similar to constructivism, yet he insists that reality exists in the relationship that one has with that reality. There is no objective or external 'truth' and instead reality consists of a process of relationships. The associated axiology is described as relational accountability in which the researcher is obliged to be respectful of and assist in building relationships developed through the research.

This ontological position allows kaupapa Māori understandings to exist alongside other forms of knowledge in a way that is not oppositional or hierarchical. Doherty (2010) explains how the term 'kaupapa Māori theory' was developed by Graham Hingangaroa Smith as a theoretical tool specifically to achieve this. A kaupapa Māori stance offers us the space within academic institutions and academies to contribute in a way that asserts the legitimacy and validity of Māori knowledge, language and culture. Also intrinsic to a kaupapa Māori approach is an analysis of the broader socio-cultural reality in which the research takes place. This stems from the relationship between kaupapa Māori theory and its roots in critical theory, as illustrated by Graham Hingangaroa Smith (2012). Smith stipulated that a structural analysis of conditions is necessary to inform the action put into place and is crucial for kaupapa Māori praxis.

In relation to the field of health, Durie (2012) describes kaupapa Māori as reflecting an approach to clinical practice that recognises Māori perspectives. While these approaches may not differ substantially from conventional treatment methods, he stipulates that these perspectives have 'the potential to lead to great things for the people getting benefit from it. Kaupapa Māori therefore adds value to what is inevitably part of bigger system, and Māori are part of a bigger system' (p.26). 


\subsection{Methodology}

Within this study, methods and techniques from constructivist grounded theory ${ }^{13}$ (Charmaz, 2014) will be used for the secondary analysis of data gathered during clinical practice. The relationship between grounded, critical and indigenous theory is explored by Denzen (2007). He argues that grounded theory can be localised and adapted to support empowering or emancipatory imperatives that reject or directly thwart colonial hegemonies. A local example of this is demonstrated by Pohe (2012) who contends that grounded theory is well suited to a kaupapa Māori approach as it does not impose a preconceived theoretical problem or hypothesis founded upon an epistemological base antithetical to a kaupapa Māori stance.

The use of grounded theory within music therapy research has been examined by O'Callaghan (2012) who noted it was one of the most common methodologies employed in qualitative music therapy research and encouraged researchers to elucidate their ontological standpoint. Daveson, O’Callaghan and Grocke (2008) also encouraged researchers to identify whether they would employ a full or modified grounded theory. This project utilised a partial set of grounded theory methods, aiming for the development of descriptive theoretical statements rather than theory. Because of its size, time and resource constraints, the level of saturation needed for the development of theory was considered beyond the scope of this project. Also, there were only a modest number of cases encountered during this project and the development of theory may be premature at my level of experience.

\footnotetext{
${ }^{13}$ While this project was conducted using grounded theory methods, it was suggested by examiners of this research that interpretative phenomenological analysis may have been more appropriate for this inquiry.
} 


\subsection{Data Collection}

The data used within this project was sourced from the clinical notes and reflective journal I maintained while on placement as a music therapy student within a mental health unit for adolescents at a local hospital. This data was created primarily for clinical use in keeping with normal standards of music therapy practice. The analysis of this data for research is therefore termed 'secondary analysis' as it involves taking pre-existing data, originally collected for a different purpose, and analysing this for research (Heaton, 2008).

The period of data collection lasted for six months. Because samples used in analysis were all secondary data, it was not possible to conduct purposeful or theoretical sampling (Morse, 2007) by refining data collection methods based on preliminary data analysis. Instead, convenience sampling was employed and the second, fourth and sixth months of data were all chosen to be analysed consecutively to ensure a broad range of practice and participants were represented in the project. Data relating to all aspects of clinical practice were analysed. This consisted predominantly of notes from individual and group music therapy sessions. It also included reflective accounts of interactions with rangatahi and staff from contexts outside of music therapy, such as during meal times or other therapeutic programme activities (e.g. Art classes, group outings, staff meetings, kapa haka groups). Data analysed concerned interactions with roughly 50 different individuals. While data recording ethnicity was not taken, I was aware that at least 16 of these individuals identified themselves as Māori or as having some Māori ancestry.

\subsection{Data Analysis}

Consistent with grounded theory methods, a series of iterative analytical steps were undertaken with initial codes identified during the first sample informing the analysis 
of the second sample. This in turn informed the analysis of the third and final sample by which time the codes identified had been refined and developed into broader categories.

Both inductive and deductive processes of analysis were undertaken during this project. Deductively, Durie's Te Whare Tapa Wha ${ }^{14}$ (1998) model of health was employed to analyse the data. This model was chosen as it was used as an assessment tool within the clinical setting in which this research took place. Therefore, during initial coding, any activity or process described in the data that related to the four dimensions outlined within Te Whare Tapa Whā were coded within that category ${ }^{15}$.

Inductive analysis was also conducted to discover further processes or activities that appeared relevant to this enquiry. Codes developed through this process included improvisation and withdrawal, both of which consistently reoccurred within all three data samples. As it was not initially clear how these related to Te Whare Tapa Wha , searches for further relevant literature were warranted. Processes of withdrawal were initially coded as voluntary physical exclusion (e.g. someone hiding, leaving a room), social exclusion (e.g claiming "I have no friends", bullying others) or symptomatic exclusion (e.g. being unable/unwilling to engage with others due to symptoms of a mental illness). During the iterative analytical process, these inductive codes developed into the broader category of withdrawal. This category, along with others identified through this process, informed a further search of the literature to examine how these categories may relate to kaupapa Māori models of health. This will be discussed further in the findings and discussion sections.

\footnotetext{
${ }^{14}$ An overview of Te Whare Tapa Whā is given in section 2.5 of this exegesis.

${ }^{15}$ See appendix Three for an example of this coding.
} 
Throughout each phase of data analysis, analytic memos were kept to record thoughts and ideas during this process ${ }^{16}$. These were particularly helpful during the final phase of analysis when various codes were subsumed within broader categories. In keeping with principles of kaupapa Māori research, Kaumātua (elders) and other supervisors from Te Rau Puawai and MAI ki Pōneke ${ }^{17}$ were consulted to ensure the integrity of Māori concepts was maintained and represented appropriately within the findings.

\subsection{Ethical Considerations}

Approval for this project was granted by a previous ethics committee application for students' projects that utilise a secondary analysis framework to examine phenomenon encountered while on placement ${ }^{18}$. Within this framework there are no identified research participants as the research focuses on the analysis of my own clinical notes and therefore explores my own experience and understanding of this process. This carried a much lower risk to rangatahi involved in this project who were considered vulnerable because of their age and ability to give consent while experiencing difficulties with their mental health.

However, consent was required for the vignette in chapter five. To account for this vulnerability, their informed consent was sought along with that of their whānau,

\footnotetext{
${ }^{16}$ Refer to appendix four for an example of these analytic memos.

${ }^{17}$ Te Rau Puawai is an initiative within Massey University supporting the development of the Māori mental health workforce. MAI ki Pōneke supports postgraduate students in and around Wellington and is part of an international network of Māori and indigenous postgraduate students which is hosted by Ngā Pae o te Māramatanga at the University of Auckland.

${ }^{18}$ HEC: Southern A Application - 11/41. See ethical statement on page vi.
} 
while staff and kaumātua within the unit were also consulted before they were involved $^{19}$.

To protect participants' privacy, all hardcopies of data relating to this research remained on site at the facility. Any soft copies or data on a computer was stored online and secured with a password so that it was accessible only to the primary researcher. The risk of any physical, psychological or emotional harm occurring for the rangatahi involved in this project was managed by close supervision of the primary researcher by a visiting music therapist, an academic supervisor and a clinical liaison on site. The usual health and safety and fire/emergency related risks were managed according to the policies of the hospital unit in which the research took place.

The NZSM Postgraduate Committee granted approval for this project to proceed on the condition that an academic with expertise in kaupapa Māori practice was consulted. This condition was satisfied by the involvement of a Māori supervisor who specialised in mental health who was contacted through the Te Rau Puawai scholarship programme. This is an initiative run by Massey University that focuses on Māori mental health workforce development. This supervisor became involved before data analysis began and was invaluable in providing guidance in regards to the kaupapa Māori research stance.

According to Joanne Baxter (2005), kaupapa Māori research should be Māori defined, grounded in tikanga, te reo, mātauranga and contribute to the development of Māori and Māori outcomes. As a Māori researcher, I have defined the terms of this project and consulted with kaumātua employed in the unit in which the research took place.

\footnotetext{
${ }^{19}$ Refer to appendix One and Two for templates of these consent forms.
} 
The theoretical stance taken ensures that the entire process is framed within a Māori context and Māori concepts and language have been incorporated as often as possible. While their frequency could be increased, careful consideration has been given in regards to non-Māori who might read this, particularly music therapists. Also, while I do speak te reo Māori, it is not yet at a level of fluency capable of producing a research report such as this.

In terms of grounding the research in tikanga and mātauranga, the notion of relational accountability as described by Wilson (2008) have been adhered to along with these concepts outlined by Linda Tuhiwai Smith (2012, p.124) as guidelines for researchers in Table One.

\section{Table 1: Guidelines for researchers according to kaupapa Māori principles}

1 Aroha ki te tangata (a respect for people).

2 Kanohi kitea (the seen face, that is present yourself to people face to face).

3 Titiro, whakarongo... korero (look, listen ... speak).

4 Manaki ki te tangata (share and host people, be generous).

5 Kia tupato (be cautious).

6 Kaua e takahi te mana o te tangata (do not trample over the mana of people).

7 Kia mahaki (don't flaunt your knowledge). 


\section{Chapter 4 Findings}

Using Durie's Te Whare Tapa Whā (1998), the findings will be presented in the following four sections: wairua, whānau, hinengaro and tinana. Weaving these four dimensions together is the concept of mauri ${ }^{20}$, which is the integrated life-force or vitality of an individual generated through intrinsic and extrinsic relationships. Mauri is a fundamental component of a persons' wairua and it is this dimension which receives the most attention in this section.

This is because the concepts of mauri and mana ${ }^{21}$ emerged from the data as significant in relation to ecological approaches to well-being and the benefits of improvisation, self-expression and creativity to an individuals' health. These activities were strongly represented within the data that was analysed and were also effected by social, physical and mental processes as represented in the whānau, tinana and hinengaro sections described here.

The manner in which these are expressed within music therapy practice will initially be illustrated through a waiata tītî tōrea ${ }^{22}$ activity. This activity has been chosen as it is emblematic of the connection between Māori practice and music therapy and emphasises how all four dimensions of Te Whare Tapa Whā are manifested within a single musical activity. During my practice, I used this Waiata tītī tōrea activity in a number of group music therapy sessions alongside many other activities involving singing, listening, improvising, playing instruments and sharing or discussing music.

\footnotetext{
${ }^{20}$ Mauri is described in section 2.6.1.

${ }^{21}$ Mana is described in section 2.6.2.

${ }^{22}$ Tìtī tōrea are also commonly known as tī rākau and refer to a mode of waiata using rākau (sticks). 'E Papa Waiari' is a waiata very well known to most New Zealanders that belongs to this group.
} 
These further activities will be mentioned throughout this chapter along with references to individual work.

Waiata tītî tōrea were used to encourage dexterity, strengthen wrists, enhance handeye coordination and promote unity and comradeship within groups. They are fun and challenging and are a familiar pastime for many people who grew up or attended primary school in Aotearoa. Waiata tìtì tōrea involve throwing, catching and tapping rākau (short sticks) in time with a song. The rākau used in this project were roughly 30 centimetres long and made from the kōrari (flower stem) of harakeke (flax) that I had collected from my home near Maungatautari in the Waikato. The waiata tītī tōrea described in this chapter was used in a music therapy group with these goals:

\title{
Table 2: Identified needs and aims for a music therapy group in an acute mental health facility for adolescents
}

\author{
Identified Needs: \\ - Self expression \\ - Positive engagement \\ - Enhance self-awareness \\ - Build co-operation/teamwork skills \\ - Explore/express emotions
}

\section{Aims of group:}

- Engage rangatahi in musical activities.

- For rangatahi to express themselves vocally or using their preferred instrument.

- For rangatahi to interact positively with each other.

- To enhance self-awareness and self-confidence of rangatahi by engaging them in musical activities where they must listen and respond to each other.

- To provide leadership opportunities for rangatahi within certain activities.

- For rangatahi to explore/develop their identity through musical expression.

The ways in which the musical activities promoted the achievement of these and other para-musical goals will be reported throughout this chapter. Diagrams depicting theoretical categories and codes developed through the process of data analysis will be displayed as a constellation of themes and activities related to each dimension. These will be presented at the beginning of each section before being explained in 
further detail with examples from clinical practice. While this chapter is split into four separate sections, the waiata tìtî tōrea ${ }^{23}$ is described here to reiterate the interrelated nature of the four different domains of Te Whare Tapa Wha and will be referred to at the beginning of each section to emphasise this.

\section{Waiata Tītī Tōrea}

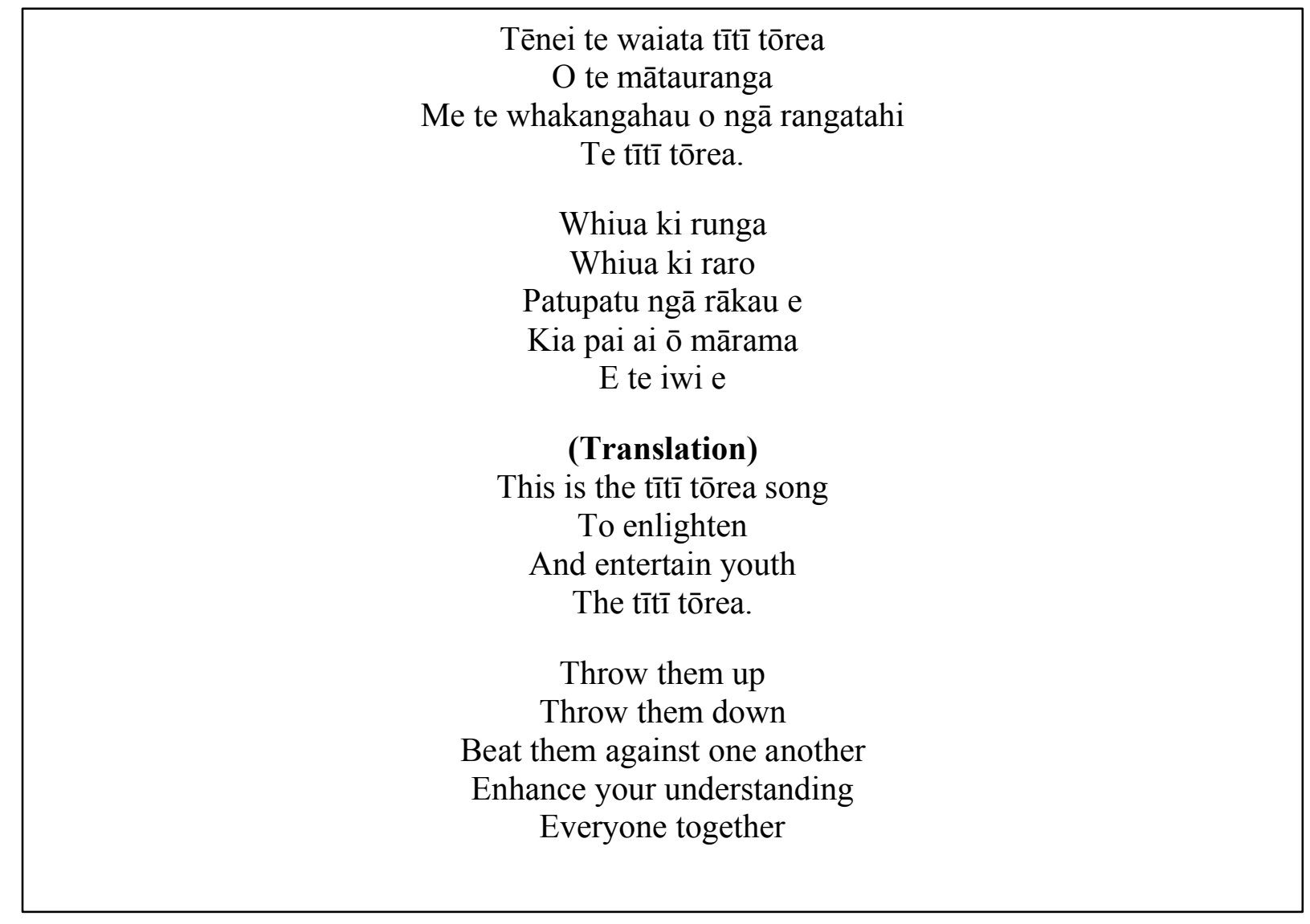

In order to create a whanau atmosphere, we all sit on the floor and take two rākau, one for each hand. I would begin singing "Tēnei te waiata tītì tōrea" and go through the first few actions. These involve tapping both rākau against the floor, flipping and catching them and tapping them together or against a neighbouring person's rākau. We work collaboratively and use our tinana to support the mauri of the waiata by singing and accentuating the 3/4 waltz rhythm with the tapping of our rākau.

\footnotetext{
${ }^{23}$ I was not able to discover the composer of this waiata, which was taught to me by my kaiako (teacher). She learnt it on the East Coast and described it as a common children's' waiata, comparable to a nursery rhyme such as 'Pat-a-Cake', that may have been adapted or modified over time.
} 
Initially it is difficult to sing and complete the actions correctly so the rākau are often tossed around or used to jab others. These cheeky little interactions decrease as the group's competence builds and new actions are invented or remembered from childhood. There is laughter and excitement as we all make mistakes and slowly begin to master the mental and physical aspects of the activity. We draw on our hinengaro to memorise the kupu (words) and coordinate our tinana so that we perform the correct sequence of actions in time with the rest of the group. We work through each section of the waiata, leaving a few minutes of practice between each before we go through it as a whânau from the beginning. Everyone is included and all are able to participate as they feel comfortable. Our wairua are supported by our engagement with others and the chance to express ourselves through singing and movement.

The entire activity is woven together by the waiata with the rhythm and melody acting as the foundation. We synchronise our tinana around the beat and this rhythm provides a common pulse that holds us together as a whanau. The melody stimulates our hinengaro and helps us to commit the song and actions to memory. Through these we physically, emotionally and spiritually express our kotahitanga (unity) and develop our whanaungatanga (sense of belonging). This also provides an opportunity to connect with our environment and culture by practicing an activity unique to Aotearoa. This sustains our wairua by emphasising our spiritual or non-physical connection with others, with our local environment and with our unique culture and heritage. 


\subsection{Wairua - The capacity for faith and wider communication.}

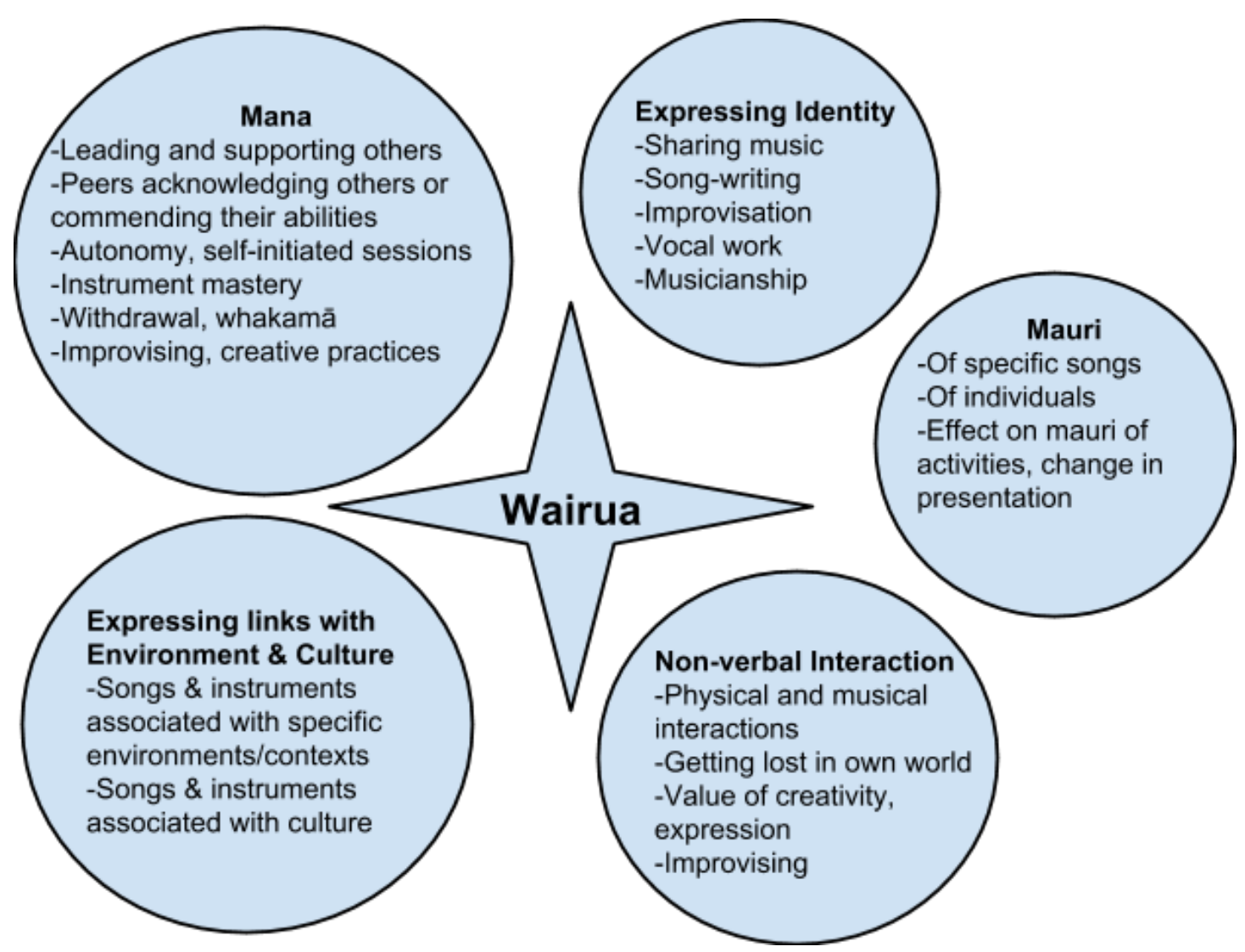

\section{Diagram 1: Theoretical Categories \& Codes relating to the dimension of Wairua}

The tìtī tōrea activity sustained and supported participants' wairua by fostering connections with the wider group (or whānau), the environment and with our unique heritage here in Aotearoa. This affects our wairua by affirming our identity and acknowledging these non-physical or spiritual connections that shape and inform it. As our mauri is that part of us connecting the physical and spiritual realms, it is supported and enhanced when we physically embody these relationships through song and action. As participant's abilities in this activity improve, their mana (charisma/authority) as performers of waiata tītī törea increases and this is acknowledged when others seek their help or commend their performance. The physical and musical components of this activity allowed rangatahi presenting as non-verbal due to their illness to interact with others and express themselves appropriately.

\subsubsection{Mana}

The concept of mana related to a broad range of activities conducted within my music therapy practice in both positive and negative ways. Positively, the mana of participants was enhanced or acknowledged through their contribution to songs and 
musical activities or improvisations. Negatively, it was exhibited when participants became physically or socially isolated by symptoms of their illness that affected their ability to interact with others.

Examples of such symptoms were when rangatahi would present as non-verbal, lethargic, aggressive/abusive, have difficulty concentrating, be distracted by internal thoughts/feelings/voices, unable to physically touch objects or engaging in selfharming or self-sabotaging behaviours. The Māori term whakamā ${ }^{24}$ (ashamed) proved valuable in relating the manifestation of these symptoms to a diminution of mana (Metge, 1986) and this concept is explored further in Chapter 6.

Despite the many difficulties these rangatahi were experiencing, all of them were able to contribute or participate musically. Those with the most acute symptoms often engaged initially on their own terms and initiated sessions themselves by approaching me in the lunch room or hallway or entering the music room of their own volition. These sessions were sometimes the first or only effort these rangatahi had made to engage with the therapeutic programme and always led to further sessions that would become more structured over time.

There were many talented and skilled musicians whose mana was acknowledged when their peers and I commended their performance or when others requested they play a certain song or instrument. Others began learning instruments within individual music therapy sessions and their mana increased as they mastered these and were able to share their improved skills with their peers in group sessions.

\footnotetext{
${ }^{24}$ While often translated as ashamed, the word whakamā has a variety of different meanings and is associated with unresponsive behaviours and feelings of inadequacy and hurt (Metge, 1986).
} 
Many activities such as group singing, call and response and group improvisations required a leader or leaders for individual sections such as one part of a round or playing the beat with a bass drum during improvisations. The mana of participants who performed these roles successfully was recognised by others within the group. Those who struggled to perform these successfully did not accrue the same level of mana but were still acknowledged for their attempt and the mana inherent in taking a risk and giving something a try was recognised. The valuing of all and every contribution in this way was deliberately fostered within music therapy sessions from the very beginning so that rangatahi with any level of musical ability or experience could participate.

\subsubsection{Expressing Identity}

Identity formation and the use of music to communicate your position within a larger social landscape are acknowledged as significant elements of music therapy practice when working with adolescents (Ruud, 1998; McFerran, 2010). The rangatahi involved in this project were able to explore and express their identity through associations with particular styles of music, by sharing songs they had composed, through improvisations or through singing and playing instruments.

The majority of participants were willing to share their favourite songs or artists and mutual appreciation of a particular artist would sometimes create a new bond between peers who did not know they enjoyed the same music. This created novel 'musical whānau' connections within the unit. I was not familiar with many of the artists who were popular so used a portable speaker to stream music from the Internet. This enabled me to incorporate any genre of music or specific artist within my music 
sessions and was invaluable when working in genres that I am not familiar with such as hip-hop or post-hardcore.

Of all the songs contained in the folder of hardcopies I used during my practice, the most commonly requested within all my sessions was 'Hallelujah' by Leonard Cohen (1984). The most commonly requested waiata was 'Te Kaiwhakaora'25, while 'Purea Nei' (attributed to Henare Mahanga and Hirini Melbourne) also appeared popular.

The sharing of songs that they had composed themselves was also a very powerful way in which rangatahi were able to express their individual identity. Some rangatahi sought assistance with this and many were comfortable sharing these compositions within group sessions after we had worked on them individually.

There was a very clear distinction between participants who were willing to sing and those who were very reluctant to do so during musical activities. The use of vocal warm-ups and rounds or choral works with more than one part proved valuable in encouraging everyone to use and share their individual voice. By splitting into separate parts the rangatahi were motivated to sing up and work together to keep their part going.

Playing instruments also offered the rangatahi an opportunity to express their musical identity as many of them were very capable musicians in their own right. Through playing particular songs they were able to align themselves with certain artists or genres and communicate this to others. They also introduced new songs to each other and were able to gain recommendations for further listening or requests for material to use in future music therapy sessions.

25 'Te Kaiwhakaora' is a waiata karakia that I learnt through Te Ataarangi, my te reo Māori class. Waiata karakia are songs using lyrics from karakia and are commonly used to open proceedings or begin an activity. 


\subsubsection{Mauri}

Mauri is the life essence that joins the physical physical and spiritual realms, unifying and animating our being. It is a dynamic force realised through a network of interacting relationships (Durie, 2001). The respected tohunga (chosen expert), scholar and Minister Māori Marsden characterised it by explaining that "Mauri is that life principle which is latent in all things... an energy behind all things... the elemental force that binds things together and gives them being" (qtd. in Metge, 1986, p. 73). Within music therapy sessions, the existence of mauri was evident in the mauri of the individuals involved and also the mauri of the waiata/song/activity that was happening at any given moment. In a manner similar to the concept of mana, mauri can wax and wane and is affected by environmental conditions and physical or spiritual processes.

This is perhaps best illustrated through the mauri of a specific song. Songs are bound together by rhythm and melody and these combine to carry a specific affect or aesthetic quality. This can be supported by different combinations of chords, bass lines or harmonies. When all of these elements are cohesive and being expressed fluidly and confidently, the mauri of the song is strong. If the rhythm is disrupted, an incorrect chord is played or any quality of a song is not expressed harmoniously, the mauri of the song is affected negatively. I experienced this when singing 'Redemption Song' (Marley, 1980) in a manner that I recognised was not authentic to the original. Although my timing and the lyrics I was singing were correct, the rangatahi I was working with immediately perceived that the mauri of the song was not intact and asked me to start again and sing it 'correctly'. 
This concept is pertinent as those songs or activities with a strong mauri are more attractive and invite participation more than those played badly or perceived as incorrect or inauthentic. As an example, 'Redemption Song' and 'Come Together' (Lennon \& McCartney, 1969) both begin with very characteristic riffs that proved to be very popular within this project. A number of rangatahi requested to learn both of these songs while others requested that I just play those catchy riffs for them. These songs have enjoyed consistent popularity with consecutive generations forming positive relationships with them. In this way their mauri has been sustained and they continue to resonate with and motivate listeners.

There were other occasions when I would attempt to play a song that had been requested by the rangatahi that I did not know well. In these instances I would not be able to offer a musical experience with a vibrant mauri. I would not know the words or be unfamiliar with the melody and would focus on supporting rangatahi who did know the song well. If nobody was willing to sing up and take the lead in these cases the song would often fail to capture or stimulate the group and we would have to move along to another activity.

Similarly, there were many situations where the mauri of the music was affected negatively by individual rangatahi falling out of sync with the rest of the group. As leader of these group situations I would have to use my music therapy skills to resolve this by connecting with their unique musicianship and incorporating it into the wider musical experience. This involved techniques such as adding an extra beat in a bar to rebalance the song or articulating the specifc key or chords so that instrumentalists were aware of these. 
At times these group music making sessions were very chaotic however, allowing us to abandon specific modes or strict adherance to a time signature. This free improvisation with no preconceived ideal for what the music should sound like was a very common method within individual music sessions as well. These were the most powerful moments I experienced while making music with rangatahi as the mauri of these pieces had an absolute singularity and immediacy to them that was unique to that specific moment.

Just as a song has its own mauri, so too do we as individuals have a vitality or life principle that waxes and wanes. All of the rangatahi involved with this research were experiencing significant difficulties with their mental health and this often manifested itself in withdrawn, anxious, shy, apathetic or inwardly reflective behaviour. These presentations can be considered as a state of mauri moe ${ }^{26}$ (Whakaatere \& Pohatu, 2011) or inactivity that is detrimental to health. Conversely then, a state of mauri ora ${ }^{27}$ (dynamic well-being, vitality) is associated with being actively engaged and highly motivated to participate.

The ability of music to invigorate and engage individuals therefore assists in moving them from a state of mauri moe towards a state of mauri ora. This was identified within this research through the change in presentation exhibited by some rangatahi during and following musical activities. This was particularly evident in the period immediately following group music therapy sessions.

\footnotetext{
26 'Moe' means sleep and when paired with mauri in 'mauri moe' denotes an absence of vitality associated with an inactive or deflated presentation.

27 'Ora' means health or well-being and suggests an essential vitality or force that generates and sustains well-being when paired with mauri in the term 'mauri ora'. This concept is explored exhaustively in relation to Māori health and broader socioeconomic realities by Durie in his book Mauri ora: The dynamics of Māori health (2001).
} 
Often during this time, when most rangatahi were leaving the room, there would be one or two who would remain behind and continue playing, request further instruction with an instrument or simply engage me in conversation. While these may sound like insignificant acts, these interactions often occurred with rangatahi who were particularly reticent and disengaged from the rest of the group. For some the interaction we had following a session was the first time I had ever spoken to them. Others began playing an instrument when they had appeared incapable of doing so during the actual session. The change in presentation in these cases was stark and this effect occurred on a number of occasions with different rangatahi.

\subsubsection{Non-verbal interaction}

The non-verbal nature of musical interactions meant that rangatahi could participate in a music therapy session without speaking at all and indeed entire sessions were instigated, a range of activities carried out and then the session completed without a single word being spoken. More common though were improvisations with rangatahi where neither of us would say a word and we would rely on our musical expressions to communicate with each other.

The meanings communicated during these improvisations were specific to that particular moment and context and cannot be described verbally. However, this process was inherently valuable in that it allowed them to express themselves in some way. This can be related to the concept of whatumanawa ${ }^{28}$ as it recognises the need to fully express and experience feelings and emotions.

Improvisations during this project usually occurred with the rangatahi and myself sitting side by side and both playing the piano although guitars, cajon, drums,

\footnotetext{
${ }^{28}$ Whatumanawa is described in section 2.6.7.
} 
mandolin and accordion were sometimes used as well. These improvisations had no pre-set boundaries and were co-created by them and I together. While they were often difficult to start, once people began playing we would both get drawn into the piece and recurring motifs would develop. These would become a sort of shared discourse that we could then revitalise in later music sessions or improvisations. When I questioned rangatahi on the meaning or value placed on their improvisations they usually found it difficult to articulate this in words. Most commonly they valued this experience as they could become 'lost' in the music. Through this process they could safely express their feelings and emotions fully and freely without resorting to negative or anti-social behaviours

\subsubsection{Expressing links with environment and cultural heritage}

The use of music to associate oneself with specific places, contexts, environments and cultures links with the expression of identity discussed earlier ${ }^{29}$. This was exhibited through the musical preferences demonstrated by the rangatahi as well as their participation and proficiency in particular activities. When rangatahi told me their favourite band or requested a song to play I would often ask where they first heard this song or what association they had with it. Many of their responses would involve a very specific context, a particular group of friends or a significant family member whom this song reminded them of. For some it was a precise place or environment that they felt particularly connected to.

For others, culturally specific activities held particular significance. This was demonstrated during the many kapa haka sessions that I attended and supported the

29 'Expressing Identity', section 4.1.2. 
kaumātua on the unit to run. While some rangatahi would thrive within these activities due to their prior experience, others would only participate with reluctance.

There were also cases where previously quiet rangatahi would step in and lead a waiata because of their familiarity and comfort within this role. This also occurred when working with rangatahi who were not from Aotearoa. In these cases I was able to learn songs in their native languages or they were able to share musical activities from their childhood with the group. This appeared to engage and involve these rangatahi within our group much more so than when we were completing activities unfamiliar to them. 


\subsection{Whānau - Capacity to belong, to care and to share as part of}

\section{wider social systems.}

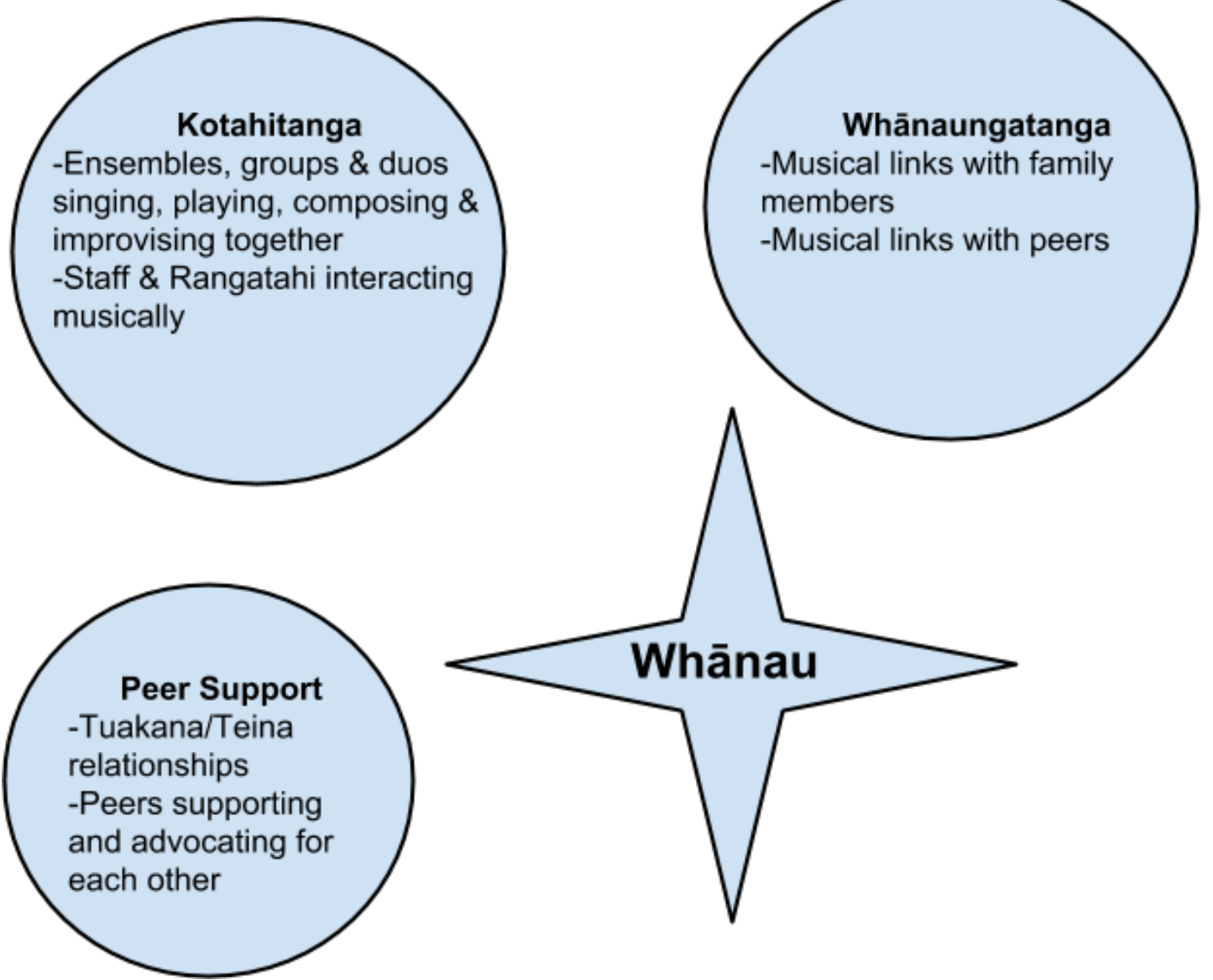

\section{Diagram 2: Theoretical Categories \& Codes relating to the dimension of Whānau}

Within the tītī tōrea activity the dimension of whānau is very clearly supported through the social interactions the rangatahi engage in while participating. This activity was valued because every group member could be included and all were able to participate as they felt comfortable. The sequence of tapping/throwing the rākau required every individual to coordinate their actions and the rangatahi were proactive in supporting each other to achieve this. The common goal of performing the waiata as a group developed a sense of kotahitanga (unity) and cultivated the group's overall feeling of whanaungatanga (connectedness). 


\subsubsection{Kotahitanga}

Within group sessions we engaged in group improvisations, singing and playing popular songs, small duo or ensemble work and group singing activities. These activities established a sense of unity within our group as we had to work together to complete them successfully. This developed a sense of belonging that began when we sang 'Purea Nei' together at our morning meeting. Every individual contributed in unique ways during group activities and these contributions would all be woven together to produce the collective musical experience.

Any contribution was valued within these group sessions and it was sometimes very difficult to include everyone equally when there were large discrepancies in musical preferences or abilities. This necessitated a flexible approach in which rangatahi could contribute as little or as much as they preferred and choose from a range of different instruments to work with.

This enabled those with no experience on the guitar, piano or mandolin to participate by using the cajon, an egg shaker or other small percussion instruments. Others chose just to sing and some preferred simply to listen. Initially I presumed those sitting and listening were not engaged or motivated by the musical experiences I was facilitating. However, I received feedback from some of these rangatahi who appeared disinterested during sessions that they did in fact really value just listening or contributing very minimally to the music ${ }^{30}$. Although they were not leading a song or playing the main instrument, they still felt part of the group and included within the process. This flexibility of group roles and boundaries was valued in this context as

\footnotetext{
${ }^{30}$ This is documented in the clinical vignette in chapter 5.
} 
rangatahi often felt isolated and excluded due to their inability to engage or participate in socially acceptable ways.

\subsubsection{Peer Support}

As the unit only has a small number of beds, all the rangatahi were very familiar with each other and were generally very aware of each other's diagnosis and associated symptoms or behaviours. This usually resulted in a very supportive and considerate atmosphere. While there were instances of bullying and other forms of abusive behaviour or mistreatment, the rangatahi were generally very conscious that everyone had their own unique challenges and worked to help each other overcome these.

Within music therapy sessions, this manifested itself in a wide variety of pro-social behaviours that relate to the Māori concept of ako and tuakana/teina relationships ${ }^{31}$. In group settings, more experienced musicians supported their less experienced peers by teaching them new chords or leading groups when singing rounds so that those less confident could follow them.

Rangatahi would often advocate for their peers as well. Many times when I asked what we should do next, someone would volunteer a friend of theirs who they knew could play or sing a particular song well. There was also a lot of positive reinforcement when rangatahi did share a song and this was particularly valuable when individuals shared their own compositions.

\footnotetext{
${ }^{31}$ Ako is translated as learning but does not equate with this exactly. The concept of ako describes a reciprocal exchange of information where both the teacher and learner are valued as holders of knowledge in certain areas and both benefit from the exchange of knowledge. The word tuakana translates as older sibling or cousin of the same sex and teina as younger sister or cousin of the same sex. As tuakana, those who are older and more experienced have responsibility to guide and support their teina. Conversely, teina are encouraged to reciprocate this assistance by respecting and supporting their tuakana.
} 
The concept of ako was also demonstrated through the way in which we would all share and learn from each other. Although I lead the groups, I was careful to call it 'our music group' and always negotiated what musical activities we would share together. Through this process I learnt a huge amount about different bands and artists I had never listened to before. I also learned new skills on the mandolin and the drum kit from rangatahi who were very skilled musicians. Many of the rangatahi involved developed their skills on particular instruments or their confidence in a particular area and were then able to share this or encourage this in others. In this way it was recognised that all of us were experts in our own way and that we all had something of value to contribute to the group.

\subsubsection{Whānaungatanga}

Everyone is included as part of the whānau at the unit. This familial identity is actively encouraged by the staff and supported strongly by the kaumātua who work hard to build relationships with rangatahi and encourage them to build positive relationships with their peers. For rangatahi who had recently arrived or whose symptoms were particularly acute, music therapy sometimes provided an initial point of engagement where they would begin to interact with staff and peers before they began to participate in the regular daily programme.

When discussing musical tastes or particular instruments, immediate family or wider whānau members were often acknowledged by rangatahi as the source of their preferences. This was indicated through statements offered such as "my sister/grandfather/cousin plays the guitar/mandolin/accordion" when I brought out an instrument or "my older brother listens to heaps of hip-hop/heavy-metal" when I questioned where they had encountered a certain song or band. Usually these 
references to whānau members were very positive and sometimes this contradicted the manner in which they described their relationship with their whānau when speaking with other staff.

There were also instances where individuals were reminded of family members or friends who had passed away. For some the recollection of emotions brought on by music associated with their deceased whānau was too painful and they were unable to play certain songs or instruments any longer. Others composed songs in tribute to those people important to them. This demonstrated the powerful emotional associations music maintained in relation to whānau for the rangatahi. Music provided an avenue through which the rangatahi could emphasise their connection to a whānau they associated themselves with and communicate this association with others. 


\subsection{Tinana - Capacity for physical growth and development.}

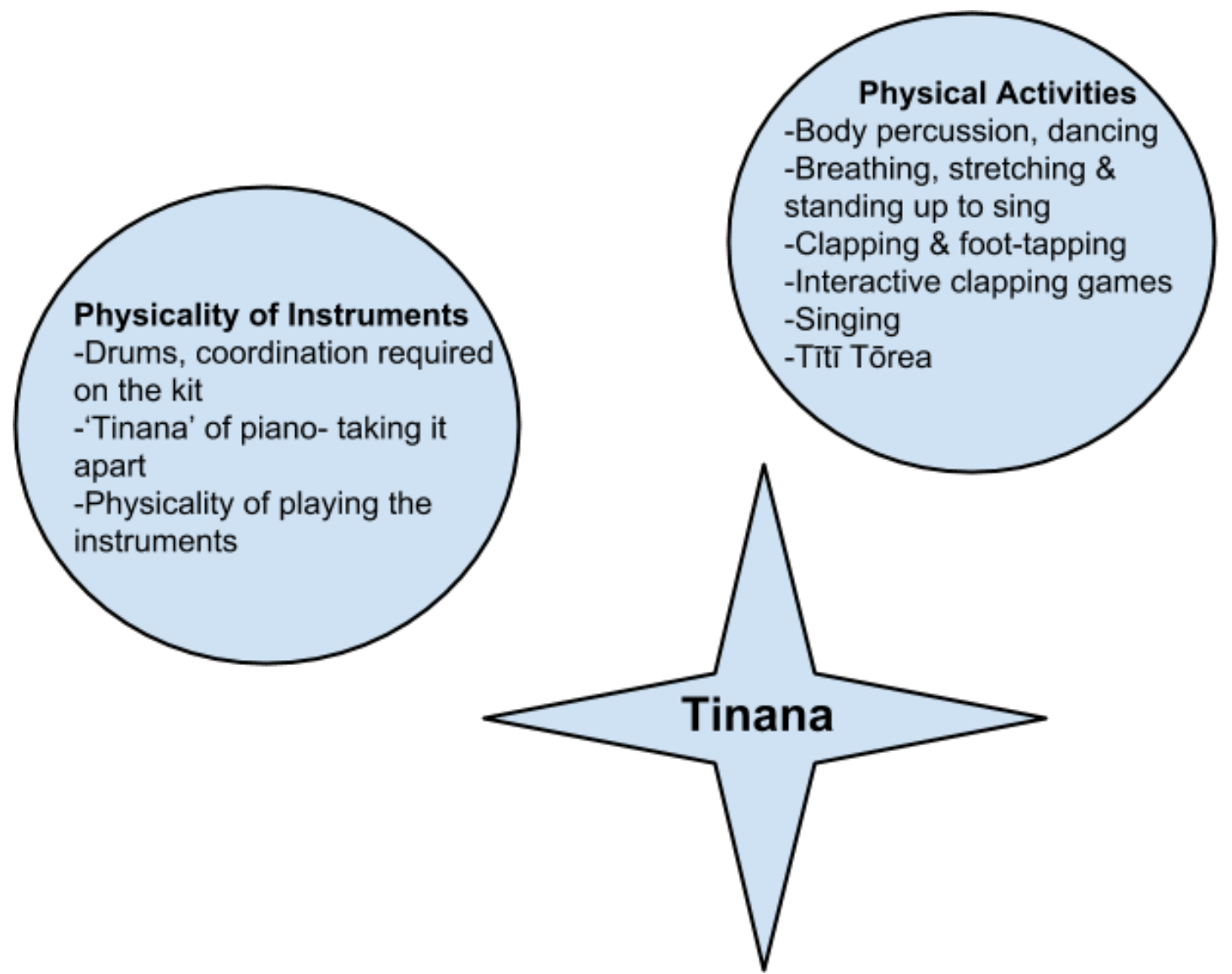

\section{Diagram 3: Theoretical Categories \& Codes relating to the dimension of Tinana}

The waiata tītī tôrea activity is very physical, requiring participants to use their voices and lungs to sing while manipulating the rākau in a precise sequence. These non-verbal components enabled the rangatahi to participate in ways that were relatively inconspicuous, especially as everyone was focused on their own rākau. This made the activity very inclusive as rangatahi who were less involved in vocal or instrumental activities could participate just by holding the rākau and completing simple actions. This also encouraged them to engage with peers as the sequence of actions required interacting with others by tapping their neighbour's rākau or throwing rākau between two people.

The more active rangatahi concentrated very diligently, focusing on mastering the moves and memorising the lyrics. These complement each other as the actions physically prompted us to remember the correct words and vice versa. As my group session always ran during a time slot following lunch, the physical movement inherent in this activity allayed any attempts by the rangatahi to sleep or doze on a couch. 
Instead it required them to be fully present in the moment with the rest of us and to focus and concentrate so we could complete the waiata successfully as a whannau.

\subsubsection{Physical Activities}

Within the data examined for this research, the physical aspects of music therapy activities were often used as warm-up activities. Body percussion activities, dancing or action songs, breathing and stretching before singing and interactive hand-clapping games were all used to initiate sessions or reinvigorate groups when motivation began to wane. Activities involving direct physical interactions were valued as they invited interactions with rangatahi who were not prepared to sing or sound instruments independently.

While participants were often reluctant to engage at first, their enjoyment and engagement usually increased significantly once the musical activity was underway. On one occasion this occurred for an entire group with the well-known waiata 'Mahunga, Pakihiwi, Puku, Hope, Waewae' (Head, Shoulders, Knees \& Toes). The Kaumātua and I initially struggled to motivate all the rangatahi just to stand up from their seats to complete the actions of this waiata. Once the music began and the tempo began accelerating however, there was very active participation and plenty of laughter and enjoyment as the rangatahi rushed to complete the actions in time with the music. This demonstrated the way that music and physical activity complement each other and are able to motivate and invigorate participants when combined.

\subsubsection{Physicality of Instruments}

Playing all of the instruments involved some physical movement. This was particularly relevant when rangatahi played a hand drum, the cajon or the drum kit. These instruments provide immediate physical, acoustic feedback in response to 
physically tapping or beating them and were used very expressively by rangatahi during music sessions. These and the piano were the loudest instruments available and this appeared to appeal to a number of rangatahi who played these instruments very freely and expressively, transposing their physical movements into outbursts of music.

At the opposite end of the spectrum were the smaller and softer instruments, small percussion equipment such as egg shakers, metallophones or tambourines that require only a tiny movement to create a sound. Some rangatahi appeared to favour these, consistently choosing them in our group sessions and using them to contribute in a way that was not so overt as those playing the bass drum or guitar.

These appeared to be valued for the ease with which they could be played. Instruments such as the metallophone only required a light tap with a beater to produce a satisfying sound and I was able to remove certain notes to leave only those in the key fitting certain activities. This was often shared between two people and I noticed that this sharing of instruments was very valuable in individual sessions.

While I improvised with rangatahi using a range of different instruments, I found that sharing the piano was the most effective in eliciting their full and confident participation. Playing the same instrument meant that the sound was coming from the same place and we were collectively constructing the music together. If we were on two separate guitars this physical barrier delineated a clear distinction between 'my music' and 'their music'. On one occasion I also took apart the piano to display its 'tinana' to te rangatahi I was working with. We explored the mechanics of it together and I demonstrated how the hammers inside functioned similarly to percussion instruments as this person was particularly fond of the drum kit. 


\subsection{Hinengaro - Capacity to communicate, to think and to feel}

\section{emotions.}
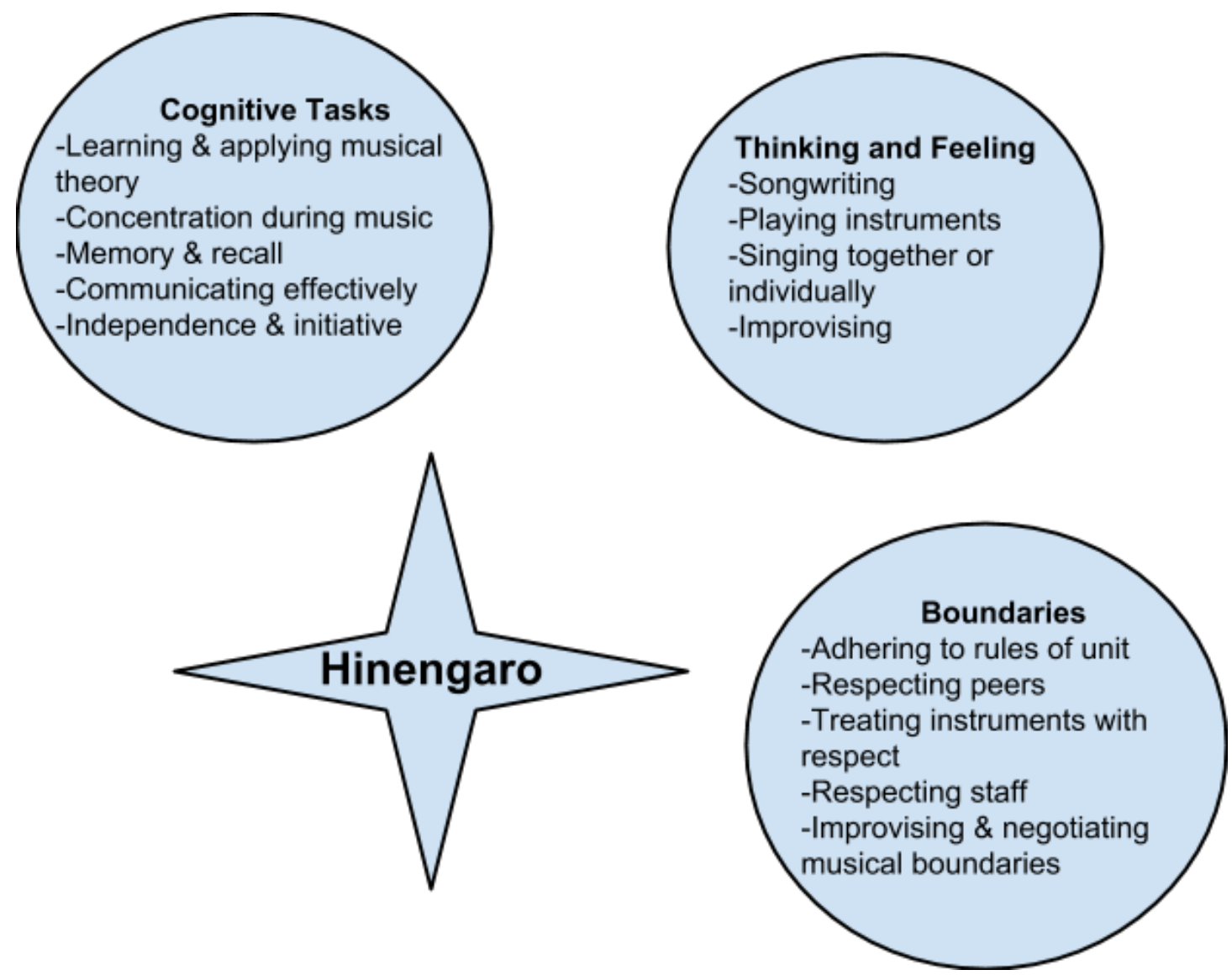

\section{Diagram 4: Theoretical Categories \& Codes relating to the dimension of Hinengaro}

The waiata tìtī tōrea was a very taxing cognitive task when first attempted. Learning to toss the rākau correctly while singing the words required sustained concentration and practice to master. It required that participants remain aware of the group as a whole, attending closely to the actions of their neighbours and peers in order to coordinate the moves correctly.

Once they become adept with these they were encouraged to sing simultaneously and then the tempo was increased when they became competent with the words and actions. Despite this complexity, this activity appeared more accessible than other musical tasks and always involved every single group member. In some cases participants who did not think they could do it and initially refused to join in later proved to be the most proficient and began teaching their peers and other staff 
members. Emotionally this activity elicited laughter and joy from participants as well as frustration when it was not executed correctly.

\subsubsection{Thinking and Feeling}

The ability to regulate emotions or emotional response and to rationalise behaviour or justify thoughts and actions is a function of the hinengaro. These closely resembled the specific goals for many rangatahi involved in this research who dealt with their emotions through negative or anti-social behaviours. These could be externally projected through violence and aggression towards others or internally manifested to produce low self-esteem or self-harming behaviours.

Music therapy sessions provided a space in which rangatahi could express their emotions in a safe and socially acceptable manner. Activities promoting this expression included improvisation, composing original songs, playing instruments together with a group or individually and also singing or listening to songs chosen by the rangatahi. Thoughts and feelings within these activities were expressed both verbally and musically.

Verbal expressions included self-composed lyrics and comments or thoughts expressed when discussing a song or activity. Some songs were described as depressing while other songs were considered motivating. Comments following improvisations varied significantly with some described as chaotic or impulsive while others were calm or sleepy. This use of emotional terms to characterise these musical activities demonstrates that these activities were understood as emotional expressions although these often appeared difficult to describe verbally. 


\subsubsection{Cognitive Tasks}

Every activity included in music therapy sessions within this research involved some cognitive component. These included relatively simple tasks such as listening, singing from a song sheet or playing simple rhythms with percussion instruments. More advanced activities included improvising or singing using specific scales, studying and applying musical theory, learning sequences of chords, new fingering patterns or chord inversions on different instruments. The suitability of these tasks varied dramatically for each rangatahi.

The therapeutic value of these usually related to any changes observed in an individual's conduct or capacity for these cognitive tasks rather than a weighting of performance on any one measure. Typically, rangatahi who were acutely unwell would gradually begin to engage in more complex cognitive activities as their health improved and their familiarity with the musical tasks increased. If the rangatahi presented as non-verbal, refused to attend school or actively engage in formal cognitive assessments, their participation within music therapy sessions proved particularly valuable to the wider therapeutic team.

This was because their engagement in music provided information about their ability to express themselves and communicate with others, gave insight into their social interaction abilities and also their concentration and memory skills. Their capabilities in these areas could then be taken into consideration when making diagnoses, monitoring the effects of pharmaceutical interventions and planning further therapeutic interventions or for discharge. These aspects of the hinengaro dimension are particularly relevant to the clinical vignette presented in chapter five. 
The use of initiative within sessions and the assertion of independence within groups were also represented within the data analysed. Many activities required cooperation between peers such as interactive hand clapping, singing rounds, polyrhythmic percussion activities and activities that specifically required everyone to play their own short solo section. Within these each individual rangatahi needed to remain aware of and focused on their own contribution while simultaneously integrating it with the music of the entire group.

Less structured improvisations allowed rangatahi to explore different instruments and use their initiative to experiment with different sounds that they could add or contribute. The flexibility in these activities encouraged creativity and spontaneity in our playing and rangatahi often swapped instruments or tried new playing techniques during these activities.

\subsubsection{Boundaries}

When choosing songs within music sessions, rangatahi had to ensure they would not offend their peers or other staff members. This was particularly pertinent when using rap or hip-hop songs as these genres often contain lyrics or themes that are misogynistic, explicit or homophobic. Negotiating song choices therefore led to valuable discussions with rangatahi about the messages that songs convey.

This encouraged them to discuss their own morals and values and recognise how they may differ from others' in order to understand why certain music was not appropriate within certain environments. Open discussion of these boundaries invited the rangatahi to censure their musical requests themselves, thereby internalising what was acceptable or appropriate to others. 
The negotiation of boundaries became more prominent within the later data samples and became the central focus of music therapy sessions with some rangatahi. For those who refused or were unable to participate in formally structured groups or school, music therapy sessions provided a space where they could be spontaneous and participate on their own terms.

As sessions progressed familiar routines or behaviours would emerge. The development of my relationship with them or their affinity for certain instruments, songs or styles of playing then motivated them to remain engaged for longer periods of time or to join others in similar activities. As their capacity to participate appropriately increased, greater expectations were placed on them and new challenges were introduced. In this way acceptable behaviours and the boundaries stipulating these remained fluid and were developed in tandem with each individual. 


\section{Chapter 5 Vignette}

While on placement I worked with many different rangatahi and it was always unique and developed in different ways. Because the length of stay was different for every individual, my work with longer term admissions developed much further than it did with those who were only resident on the unit for a week or two. For this vignette, I have chosen to describe my work with $\mathrm{Jean}^{32}$ as it stretched over a longer period of time and illustrates how music therapy was able to support the goals of the wider multidisciplinary (MDT) team in a relatively complex case.

Jean and I began working together during her first admission to the unit, which occurred at the beginning of my placement. Our first discussion was initiated when she entered the music room after recognising 'Oh You Pretty Things' by David Bowie (1971), which I was playing on the piano. This led to a few individual sessions in which she learnt 'Let It Be' (Lennon \& McCartney 1970) on the piano before she was discharged roughly one month later. Jean continued to attend music therapy however as she was readmitted a number of times over the following six months. We worked together regularly during these later admissions, both individually and within music therapy groups. Her focus switched to the guitar over this period, with Jean requesting to learn 'Blackbird' (Lennon \& McCartney, 1968) and 'Down By The Seaside' (Page \& Plant, 1975).

Jean had a history involving a traumatic brain injury (TBI) that led to some impulsive behaviour and difficulty planning as well as a decrease in her academic performance. Her first admission to the unit occurred as she was experiencing psychotic symptoms including persecutory delusions, thought disorder, hearing voices and social

\footnotetext{
${ }^{32}$ This name has been changed to protect the privacy of this rangatahi.
} 
withdrawal. She openly discussed her polysubstance abuse and a diagnosis of schizophreniform disorder during a later admission was suspected to be drug induced. Goals decided upon in an MDT meeting during this time were to encourage contact with whānau and friends and assess levels of concentration and participation.

It was not known to what extent the TBI had affected Jean cognitively. While her performance at school had decreased, this had also been attributed to behavioural factors. Because of this, the hinengaro dimension of health was very prominent when working with Jean. She was a very interesting conversationalist and appeared to me to possess a very capable intellect as she was comfortable discussing very abstract ideas, such as Jungian psychology or string theory.

In relation to wairua, she openly discussed non-physical phenomena, professing an ability to perceive people's auras. She also once described herself as an 'empath' who felt or experienced the emotions of others around her. This led to a discussion about music therapy and music in general with its latent capacity to express and share internal thoughts and emotions with others.

Jean had a strong affinity for verbal expression, writing profusely in a notebook that she carried with her. She did however have difficulty articulating her thoughts so she could communicate them clearly and coherently to others. Because of this she related strongly to the lyrics of 'Across the Universe' (Lennon \& McCartney, 1970a), a song that featured in the latter stages of our music therapy work together.

I believe that our relationship was strengthened by our mutual affinity for rock music from the sixties and seventies, including artists such as David Bowie, The Rolling Stones, Pink Floyd and The Beatles. She attributed her appreciation for this generation of artists directly to her whānau, with one of her parents possessing a 
comprehensive record collection that she had spent many hours listening to. She spoke about this connection with her whānau very affectionately and also mentioned how she associated some of these songs or artists with specific groups of friends and environments in her hometown.

The dimension of tinana was exhibited through Jean's behaviour and physical presentation. After one of her readmissions, staff noted that she appeared physically less healthy. This was expressed in her posture and behaviour as she chose to spend a lot of time sitting slouched in the hallway, remaining detached and isolating herself from others. Jean's level of engagement with others appeared to increase the longer she was resident on the unit. Initially she claimed that group sessions were 'too much' for her and then after a few weeks she would start to attend regularly.

The relationship between tinana and hinengaro was clearly demonstrated when Jean was learning the song 'Blackbird'. As she was only just beginning on the guitar, this was quite a complex song to learn as it required that she memorise an extended sequence of different finger shapes with her left hand and pluck the correct strings with her right. While learning this, Jean would always return to the very beginning and go through the song from the top every time she made a mistake. She stated that she could only remember the song and where to place her fingers if she physically went through this process. I recognised this strategy from my own experiences learning the guitar and we discussed this incredible ability whereby our fingers could remember the song while our head could not.

This strategy proved successful for Jean, who learnt the entire intro and verse section for this song. She declared that this was the first thing she had 'stuck to' in years and also felt that her memory had improved as a direct result of her musical practice and 
dedication to learning this song. I was able to report this during an MDT meeting and also comment on Jean's ability to concentrate and participate during sessions. This fluctuated significantly, with Jean sometimes applying herself diligently for a full hour and other days only able to manage ten or fifteen minutes.

She was very aware of her capacity in this regard and would comment that she 'felt like shit' on certain days and excuse herself early because of her fragile or disordered state of mind. These days did not occur frequently and when I questioned her she was unable to attribute these difficult states to any particular cause. The fact that she was able to apply herself earnestly for a full hour when in a good state of mind was of value to the wider MDT however as it demonstrated that she was capable of doing so. This information was valuable when considering potential diagnoses, suitability for discharge and assessment of the effects of pharmaceutical interventions or her ability to return to school or enrol in further education.

Within group sessions Jean tended to remain quite inconspicuous, often choosing to play a keyboard, metallophone or drums. These would generally be played quietly, hitting the rim of the drums softly rather than beating them loudly in the centre. She would usually sing along but did not appear to engage wholeheartedly in these group activities. In the early stages of my student placement I interpreted this negatively and assumed her mellow presentation was my fault for failing to excite or motivate her to participate. However, she approached me at the conclusion of an early group session to thank me and tell me she hadn't realised music could be used therapeutically in groups like this.

This challenged my own conception of what it meant to 'participate' in a group and meant I was much more comfortable in the future with group members just sitting and 
listening during activities. It also became apparent later on that her minimal amount of participation was not due to a lack of confidence. After learning the lead for the intro to 'Down By The Seaside' on the guitar, she was happy to perform this in our group with myself and other rangatahi playing chords in accompaniment. When I complimented her on her confidence in doing this in front of her peers she appeared to think nothing of it.

She was also very comfortable improvising on the drum kit, which was a new addition to the music room during the last two months of my placement. Rhythmically, she was capable of maintaining a steady, reliable tempo and could comfortably ascertain where the beat was in a piece of music and begin playing along. When working with others she was also able to play specific rhythms that I requested. For example I was able to ask her to play in $6 / 8$ or $4 / 4$ timing to provide the beat for myself and other rangatahi to play specific songs using other instruments such as mandolin, guitar or piano.

In our final few sessions together she predominantly played the drum kit, requesting that I play some jazz pieces on the piano or just improvise freely with her. By this time we were very familiar with our individual styles of musicianship and could improvise together very comfortably, responding to each other's playing and exploring new techniques without any sense of unease or anxiety.

Jean also played 'Let It Be' on the piano during one of her final music sessions, surprising me as I had not heard her play it on the piano since teaching it to her when we first began working together. I believe that this song supports our wairua by providing solace and expressing a profound trust in the universe in letting circumstances 'be' as they are. For this reason, I found this particularly appropriate 
within this mental health unit as many of the rangatahi I worked with appeared to feel disoriented and despondent in relation to their present circumstance.

Jean expressed a sentiment indicating this at one point, saying she felt institutionalised by her experiences in this unit. I challenged her on this, saying that institutionalised was quite a harsh term, and reassured her that she would still be able to live freely and functionally when she left the unit. She agreed that she was capable of doing so but maintained that her time in the unit had changed her in both positive and negative ways.

Her musical development was one of the positive changes that she acknowledged and she thanked me for my patience while working with her. While I was fortunate that Jean and I shared some musical preferences, I adapted most of the songs we worked on to her level of proficiency before teaching them to her on guitar and introduced discussions of the themes we felt the music conveyed. This was beneficial as Jean experienced some difficulty articulating her own thoughts and ideas and we were able to discuss how music could express incredibly delicate or universally expansive ideas in such a succinct manner. I also specifically enquired as to her relationship with these songs, where she had discovered them or whom she had listened to them with, and gained some valuable insight into her whānau relationships through this process. The connection between her hinengaro and tinana was apparent in her ability to recall songs when physically playing through them in sequence and also in her ability to coordinate her playing on the drum kit in time with other musicians. In recognition of 
the concept of $\mathrm{ako}^{33}$, Jean also provided me with valuable feedback about my own practice and introduced me to some new songs that I continue to enjoy.

${ }^{33}$ This is described in section 4.2.2 Peer Support 


\section{Chapter 6 Discussion}

This research indicates that a range of aspects of kaupapa Māori health models appear to relate to music therapy on both a theoretical and a practical level. This relationship is complex, and is mediated by cultural and epistemological differences. In spite of this, the understandings of well-being articulated in both of these fields appears complementary.

On a theoretical level, the concept of hauora (health/well-being) expressed by kaupapa Māori health models appears to share some commonalities with ecological understandings of health in music therapy. In both of these fields, the concept of hauora/health is articulated as a network of interrelating dimensions that support or sustain a persons' well-being. While these dimensions are culturally defined within kaupapa Māori health models, both approaches stipulate that these dimensions are not identical within every individual but reflect the unique relationships people maintain within their own social, cultural and environmental milieu.

The four dimensions of wairua, hinengaro, tinana and whānau within Te Whare Tapa $^{34} W h \bar{a}$ and the eight dimensions described within Te Wheke ${ }^{35}$ all stem from a kaupapa Māori understanding of hauora. The acknowledgement that these different domains all interrelate and affect an individuals well-being is comparable to the ecological understanding of health articulated by DeNora (2013). DeNora describes health as a phenomenon made up of interrelating dimensions, which are mediated by environment and culture and fluctuate over time.

\footnotetext{
${ }^{34}$ This model is described in section 2.5

${ }^{35}$ This model is described in section 2.6
} 
This understanding of health is adopted by Ansdell (2014), who formulates an ecological approach to music therapy that acknowledges these dimensions. These dimensions impact upon an individual's experience of music resulting in paramusical ${ }^{36}$ relationships that inform how the musical interaction can affect their health. Specific dimensions are not defined and instead these para-musical domains refer to all physical, mental, individual, relational, social or political phenomena associated with musical activities in a specific social, cultural or environmental context.

Therefore, an ecological approach to music therapy would appear to fit well within a kaupapa Māori health service. This is because the dimensions of health proscribed within kaupapa Māori health models are readily acknowledged as fundamental to the process of maintaining or supporting well-being. For this to be effective however, familiarity and appropriate understanding of the concepts within these models is essential.

On a more practical level, particular concepts within these kaupapa Māori health models appear to resonate with the therapeutic motivations underpinning the use of creative and expressive activities within the music therapy practice analysed. The concepts of mana, mauri, whatumanawa and whakamā appear particularly relevant to music therapy within the context examined by this research. These concepts are formulated slightly differently within the two kaupapa Māori models of health used in this study.

While Te Whare Tapa Wha was used by the unit in which this research took place and as a framework for deductive data analysis, concepts that are articulated distinctly within $T e$ Wheke emerged as significant within the music therapy practice examined.

\footnotetext{
${ }^{36}$ The term 'para-musical' is described in section 2.9.
} 
These concepts of mana, mauri and whatumanawa are not specified within Te Whare Tapa Wha , but this does not mean they are excluded from it as they would each be associated with the wairua dimension.

This is a significant finding in itself as the dimension of wairua was singled out by my Māori supervisor as the domain that I would predominantly be working within. This supervisor was not a music therapist but worked in the field of adolescent mental health, specifically focusing on preventing suicide by Māori youth. The first time we met and began discussing the therapeutic use of music within this context he immediately acknowledged wairua as the most relevant domain. I found this when discussing my research with fellow Māori in different contexts as well. When explaining my research and the practice of music therapy in te reo Māori I use the term 'whakapiki i te wairua' which translates as 'support/promote the wairua' to describe the focus of the work. Through the use of this concept I find it much easier to explain the process of music therapy in te reo Māori than I do when speaking in English.

The centrality of the spirit in the process of music therapy is also acknowledged by the indigenous scholar and music therapist Carolyn Kenny who acknowledges spirit as guiding her clinical work (Kenny \& Hadley, 2013). Kenny describes the process thus:

I basically sit down at the piano, we get very quiet, and then I say, "Play." That's it. Intuitively, I just follow, and I don't take time to logically analyze what's going on. I trust spirit to guide me through that process. (p. 20).

Kenny then describes how she is reluctant to frame her practice in this way in some contexts, but that, as an indigenous person, as a Haida, the spirit informs everything 
she does. She qualifies this by explaining that this does not mean she abandons her theoretical understandings of music therapy, only that these come afterwards when analysing the process and ascertaining how it transfers into everyday life.

Within this article, Kenny also specifically refers to the term mana as it is understood by Māori. When writing about the importance of respect and maintaining respectful relationships, she refers to the ethical principle articulated by Smith (2012) 'Kaua e takahi te mana o te tangata (do not trample over the mana of people)' that is contained in the ethics section of this exegesis in Table One. Through this research, I found the concept of mana very relevant to my own practice, particularly in relation to improvisation, but the importance of maintaining respectful relationships also correlates with the enhancement or diminution of mana and the term whakamā discussed later in this chapter.

When conducting my data analysis, I coded improvisation within the domain of wairua yet struggled to find a clear connection with the Māori models of health I was using. A further exploration of the literature revealed that this could be articulated using the concept of mana. This also introduced me to the the associated state of whakamā which provided a uniquely Māori understanding of the many different behaviours of withdrawal exhibited by rangatahi in this project.

In regard to mana, I found publications written by the prominent Māori academic and musician Te Ahukaramū Charles Royal suitable for describing the process of improvisation within my music therapy practice. As mana is a very complex term, this discussion will only contain a brief précis of Royal's arguments for the value and significance of mana as a concept. 
In a keynote delivered to the New Zealand Psychological Society, Royal (2006)

asserts that mana lies at the heart of human well-being, enabling us to feel empowered and illuminated. In practice, Royal describes a mana-inspired way of acting as one that enhances connections and harmonises relationships with others. In relation to health Royal states that "a healer with mana is not a person who merely administers medicines but who gains insight into a person's health difficulty and thereby finds a pathway" (p. 203).

The connection with improvisation is revealed when Royal construes the traditional Māori view that the fullness or peak of life is experienced when mana flows into the world and into people. He argues that a person's creativity and the way they apply their unique skills and talents provides evidence for the presence of mana within the individual. In this way we can view the practice of creative improvisation within music therapy sessions as facilitating the flow of mana within the rangatahi we are working alongside.

As mana is an important component of one's wairua, this articulation of mana through improvisation assists in supporting and sustaining an individual's wairua. This can be related to music therapy through the concept of liminality (Ruud, 1995; Aigen, 2014) that refers to the state of flow experienced during musical activities which allows participants to transcend social roles and boundaries and express themselves wholly and authentically within the moment. Sausser \& Waller (2006) also provide a link to music therapy with adolescents through their valuing of creativity and self-expression as assisting to enhance independence and self-esteem.

The ability to engage in free and uninhibited expression through musical activities is also acknowledged as a necessary activity for the maintenance of health through the 
concept of whatumanawa, one of the eight tentacles of Te Wheke. This appears to resonate strongly with the valuing of creative expression within music therapy and articulates the relationship with creative endeavour and well-being very coherently. Through this valuing of creative expression, the experience of particularly strong or overwhelming feelings or emotions is not regarded negatively, but is valued for providing creative impetus and encouraging individuals to express their identity (Pere, 1991).

Royal also notes that the concept of mana is strongly related to identity (2006). In this way we can ascribe value to improvisation and creative musical expression as rangatahi are able to assert their unique individuality through this process. This supports identity formation, which is identified as a central aspect of adolescent health by the music therapist Katrina McFerran (2010). The associated aspect of connectedness that McFerran identifies can also be related to mana through Royal's assertion that mana-inspired actions foster and enhance relationships and connections with others.

While mana has thus far been discussed in its capacity to encourage and facilitate growth and development, it is also heavily entwined with the concept of whakamā. Like mana, this concept is very difficult to translate into English. This is demonstrated in the work of respected social anthropologist Dame Joan Metge, who authored a book detailing the intricacies and differrent manifestations of this concept (Metge, 1986).

While often translated as ashamed, Metge (1986) details how whakamā has a variety of different meanings and is associated with unresponsive behaviours and feelings of inadequacy and hurt. Metge divides the outward signs of whakamā into five different 
categories. The first four are characterised by physical withdrawal or the diminution of interaction with the environment and the fifth characterised by excessive or boisterous behaviour. These differing presentations all serve to reduce social interaction and meaningful communication by limiting engagement and conversation with others.

While whakamā is not explicitly referred to in the kaupapa Māori models of health examined in this project, the behaviours that it refers to were represented very heavily in the data analysed. This is likely to have been heavily influenced by the mental health environment in which this research occurred. The findings of this study indicated that music therapy was beneficial as an intervention with rangatahi expressing whakamā behaviours.

This was demonstrated through the engagement of acutely unwell rangatahi in music therapy sessions. As these rangatahi did not engage with more structured aspects of the therapeutic programme, music therapy provided another avenue through which they could interact with others. This appeared to be beneficial in reducing their whakamā behaviours or feelings and was indicated through the increase in interaction and engagement that was regularly noted with some rangatahi immediately following a music therapy session.

The state of whakamā is also described in Metge (1986) as "a state of loss of mana" (p. 61) associated with low self-worth or self-esteem. Therefore music therapy activities that enhance or encourage the flow of mana and a more appreciative sense of self also assist in reducing the effects of feeling or experiencing whakamā. This reiterates the value of improvisation and creative expression discussed earlier as well as the positive social connections generated and reinforced through group musical 
activities such as singing, using instruments and interactive physical activities such as the waiata tītî tōrea. Peer support exhibited by rangatahi during these musical activities provided positive feedback for individuals experiencing feelings of low selfesteem or self-worth, increasing their mana and counteracting the state of whakamā.

This emphasises the value of the whānau dimension of Te Whare Tapa Whā and demonstrates how the positive social environments that developed within group music activities can benefit overall well-being. To provide a link with music therapy, the term communitas (Ruud, 1995; Aigen, 2014), referring to the camaraderie and unity developed through shared music making, may be considered complementary to the dimension of whānau.

The beneficial relationship between physical activities, cognitive processes and prosocial interactions was exemplified in the waiata tîtî tōrea activity. This clearly articulated how the domains of whānau, hinengaro and tinana interrelate to support overall well-being. The understanding that these dimensions all influence our health is comparable to that articulated by music therapists Sausser \& Waller (2006) who contended that young people grow biosocially, cognitively and psychosocially rather than just physically and mentally.

This excludes any mention of the influence of spiritual phenomena however, drawing a clear distinction between this perspective and a kaupapa Māori understanding of health that acknowledges wairua as the most essential component for health (Durie, 1985; Love, 2004). Within this dimension, an individual's mauri, their unique spirit or vitality, is acknowledged as the dynamic unifying force that binds the physical and spiritual aspects of our being together. Findings from this study indicated that music 
therapy has the capacity to affect an individual's mauri by engaging and animating them within musical interactions.

Songs or activities that were perceived as having a strong mauri also appeared more effective at motivating individuals to participate and engage within the therapeutic process. Consequently, the song that was most often requested by rangatahi involved in this research, or that could be perceived as having a particularly strong mauri, was 'Hallelujah' (Cohen, 1984). This is interesting due to the fact that this is an overtly spiritual song, much more so than other popular songs commonly used within this project. Therefore, the popularity of 'Hallelujah' suggests that rangatahi valued this spiritual aspect and sought opportunities to express this musically. This reiterates the connection between the music therapy practice examined within this research and the dimension of wairua, although connections with the domains of hinengaro, whānau and tinana are also represented throughout the findings.

While these four domains of Te Whare Tapa Wha all appear relevant within the music therapy practice examined, the significance of mana, mauri and whatumanawa within this project indicate that Te Wheke may provide a more appropriate fit for music therapy. The difference between these two models is examined by Wenn (2006) who acknowledges they are both values based and stem from an intrinsically Māori understanding of health.

Wenn contends that the impact of Te Whare Tapa Wha is restricted by the fact that it only articulates four variables and, while it has been incorporated widely within the health system, these four variables are not specific enough to ensure their meaning is not diluted when applied alongside Western models of health. Conversely, Te Wheke is acknowledged as adhering strongly to kaupapa Māori values and resisting 
adaptation to fit with Western models of health. This in turn has made Te Wheke less popular with funders of health services and this is further exasperated by its complexity relative to Te Whare Tapa Whā.

Music therapy practitioners should therefore take these considerations into account before adapting their approach to fit within either of these models. Te Whare Tapa Wha may appear simpler to apply but it is also more prone to adaptation or distortion so that it does not authentically represent kaupapa Māori values. While Te Wheke is less likely to be corrupted in this way, it does require a more intimate understanding of kaupapa Māori values that may be more difficult to access.

These values are culturally defined within a uniquely Māori epistemology and any attempt to understand them should be sought through direct experience and, preferably, with the use of te reo Māori. In keeping with the ontological position articulated by Wilson (2008), this will ensure a relational understanding of these concepts is developed and that the principle of relational accountability is adhered to.

In light of this, I would suggest any further research into the links between kaupapa Māori health models and music therapy is conducted in te reo Māori. Based on this research, Pere's Te Wheke model may warrant further enquiry along with the concepts of mana, mauri, whatumanawa or whakamā. As these are all strongly related to the wairua dimension of health, further research into the the relationship between wairua, music therapy and well-being is also suggested. In regard to music therapy, research examining the relationship between an ecological approach and other indigenous or non-Western understandings of health may assist in determining if this approach is appropriate in practice involving other cultures. The collected works of Carolyn Kenny (2006) has already generated a significant amount of discourse in this area. 
The observations of her own practice and development of theory for music therapy within The Field of Play (2006) indicate some shared foundations and philosophy between Māori and Native American understandings of health. Further investigation into the relationship between these understandings will assist in developing these further and articulating their significance regarding ecological perspectives of music therapy.

\subsection{Strengths, Limitations}

This research contributes to the development of music therapy practice that accommodates kaupapa Māori understandings of health and well-being. It also contributes to the body of literature exploring the links between music therapy and non-Western approaches to health. As kaupapa Māori models of health are indigenous to Aotearoa, the findings are unlikely to be generalisable internationally. This study is also limited by the use of the English language as nuances in understanding of kaupapa Māori concepts are not able to be fully conveyed.

As the data used in this study was collected originally for clinical purposes and written from my individual perspective, the findings relate to my own experience and understanding of my practice and do not purport to reflect the views of specific individuals or populations involved in this research. However it is hoped that health professionals here in Aotearoa will find the insights developed through this research of relevance, particularly those focused on delivering kaupapa Māori services. This research will also contribute to the body of research relating to music therapy and kaupapa Māori understandings of health. This may be of interest to music therapists here in Aotearoa and also to international practioners interested in the relationship between ecological perspectives and indigenous understandings of health. 


\subsection{Conclusion}

The understanding of hauora (health/well-being) as a dynamic phenomenon that results from interactions between a range of dimensions indicates that there is a relationship between kaupapa Māori health models and ecological perspectives of music therapy. While these dimensions are culturally defined within kaupapa Māori health models, both approaches stipulate that the relationships individuals maintain within and between these dimensions reflect their unique social, cultural and environmental milieu.

The ability of musical activities to enhance well-being is articulated as a process that supports or reinforces connections with these dimensions. This can assist in rebalancing these dimensions so that they move towards a state of harmony and unity that represents the optimum state of health. Findings from this research indicate that music is particularly valuable for its capacity to engage and interact with spiritual or non-physical phenomena. This endorses music therapy as an appropriate therapeutic intervention for supporting or sustaining an individual's wairua.

The wairua is identified as the most essential dimension of health for Māori (Durie, 1985; Love, 2004) and is strongly represented within the two kaupapa Māori health models examined in this study, Te Whare Tapa Wha (Durie, 1998) and Te Wheke (Pere, 1991). This study indicates that concepts identified within Te Wheke are particularly relevant to the process of music therapy and are defined with greater specificity than they are in Te Whare Tapa Whă. These concepts, of mana, mauri and whatumanawa, are all embedded within a Māori epistemological framework that identifies their relationship to overall health through the concept of hauora (wellbeing). 
These concepts were well represented in my music therapy practice involving rangatahi (adolescents) in an acute mental health unit. The concept of whakamā also emerged as a Māori construct that appears very relevant to the behaviour and experiences of rangatahi within this context.Based on these findings, parallels identified with the concept of hauora and ecological perspectives of music therapy indicate that ecological perspectives would be appropriate if taking an approach to music therapy based on kaupapa Māori understandings of health. 


\section{Glossary}

ĀĪō Mātua God/Goddess, the divine parents (Pere, 1991).

Ako. Teaching and learning relationship.

Aotearoa. Māori name for New Zealand.

Atua. God, Deity, Guardian, Ancestor. Hapū Sub-tribe, clan, kinship group.

Harakeke New Zealand flax, Phormium tenax.

Hauora Health, vigour, well-being.

Hinengaro. Mind, thought, intellect, consciousness, awareness.

Hui. gathering, meeting, assembly, seminar, conference. Iwi Extended kinship group, tribe, nation, people.

Kaiako Teacher.

Karakia. ... .Incantation, ritual chant, chant.

Kaumātua Elder, a person of status within the whānau.

Kaupapa Māori..... Māori approach, Māori topic, Māori customary practice, Māori institution, Māori agenda, Māori principles, Māori ideology - a philosophical doctrine, incorporating the knowledge, skills, attitudes and values of Māori society.

Kōrari Flower stem of the flax.

Kotahitanga. Unity, togetherness, solidarity.

Kupu. Word, vocabulary, talk, message, lyric.

Mana..... ..prestige, authority, control, power, influence, status, spiritual power, charisma - mana is a supernatural force in a person, place or object.

Mātauranga Māori. Māori epistemology.

Mauri..........life principle, vital essence, special nature, a material symbol of a life principle, also used for a physical object, individual, ecosystem or social group in which this essence is located. 
Mauri moe Inactive, withdrawn.

Mauri ora Motivated, aware, active, alive.

Mirimiri to rub, soothe, smooth, stroke, massage.

Papatūānuku Earth mother.

Rākau. ... Tree, stick, bat, timber, wood, spar, mast, plant.

Rangatahi Adolescents, youth.

Rangatiratanga Chieftainship, right to exercise authority, chiefly autonomy.

Reo Voice, language.

Rongoā. Remedy, medicine, cure.

Taonga Treasure, anything prized.

Tauiwi Non-Māori.

Taonga puoro Musical instrument.

Te reo Māori. The Māori language.

Te Tiriti o Waitangi. The Treaty of Waitangi.

Te Whare Tapa Whā Model of health attributed to Sir Mason Durie (1998)

Tinana Physical body.

Tī rākau......stick game - played by six or more people with wooden rods which are thrown by the players to each other in time to a song. Players sit or kneel in a circle a little distance apart from each other.

Tītī Tōrea Alternative name for Tī rākau.

Tupuna. Ancestor.

Waiata Song, chant.

Wairua Spirit, soul.

Whakamā Ashamed, shy, bashful, embarrassed.

Whakapapa. Genealogy, genealogical table, lineage, descent. 
Whānau......Extended family, family group, In the modern context the term is sometimes used to include friends who may not have any kinship ties to other members.

Whanaungatanga...............relationship, kinship, sense of family connection - a relationship through shared experiences and working together which provides people with a sense of belonging.

Whare.

House. 


\section{References}

Aigen, K. (1991). The voice of the forest: A conception of music for music therapy. Music Therapy, 10,(1), 77-98.

Aigen, K. (2014). The study of music therapy: Current issues and concepts. New York, NY: Routledge.

Ansdell, G. (1995). Music for life : aspects of creative music therapy with adult clients. London, England: J. Kingsley Publishers.

Ansdell, G., \& Pavlicevic, M. (2005). Musical companionship, musical community: Music therapy and the process and values of musical communication. In Miell, MacDonald, \& Hargreaves (Eds.), Musical Communication. Oxford, England: Oxford University Press

Ansdell, G. (2012). Steps Toward an Ecology of Music Therapy: A Guide to theoretical wanderings 1989-2011. In K. E. Bruscia (Ed.), Readings on music therapy theory, (pp. 229-248). Gilsum, NH: Barcelona Publishers.

Ansdell, G. (2014). How music helps in music therapy and everyday life. Padstow, England: TJ International.

Baxter, J. (2005). Kaupapa Māori research, epidemiology and Māori mental health: challenges, opportunities and insights. In R. Nairn, P. Pehi, R. Black \& W. Waitoki (Eds.), Ka tu, ka oho: visions of a bicultural partnership in psychology (pp. 123-146). Wellington, New Zealand: The New Zealand Psychological Society.

Baxter, J. (2008). Māori mental health needs profile. A review of the evidence: Summary. (Report). Wellington, New Zealand: Ministry of Health. 
Bowie, D. (1971). Oh You Pretty Things. On Hunky Dory [LP]. London, England: RCA Records.

Bruscia, K. E. (1998). Defining music therapy (2nd ed.) University Park, IL: Barcelona Publishers.

Charmaz, K. (2014). Constructing grounded theory (2nd ed.). London, England: SAGE Publications.

Chase, K. M. (2003). Multicultural Music Therapy: A review of literature. Music Therapy Perspectives, 21(2), 84-88.

Cobbett, S. (2009). Including the excluded: Music therapy with adolescents with social, emotional and behavioural difficulties. British Journal Of Music Therapy, 23(2), 15

Cohen, L. (1984). Hallelujah. On Various Positions [CD]. New York City, NY: Columbia.

Crengle, S., Clark, T. C., Robinson, E., Bullen, P., Dyson, B., Denny, S., ...Teevale, T. (2013). The health and wellbeing of Màori New Zealand secondary school students in 2012. Te ara whakapiki taitamariki: Youth'12. Auckland, New Zealand: University of Auckland.

Daveson, B., O'Callaghan, C. \& Grocke, D. (2008) Indigenous music therapy theory building through grounded theory research: The developing indigenous theory framework. The Arts in Psychotherapy. 35, 280-286.

DeNora, T. (2013). Music asylums: Wellbeing through music in everyday life. Surrey, England: Ashgate.

Denzin, N.K. (2007). Grounded theory and the politics of interpretation. In Charmaz, K., \& Bryant, A. (Eds.). The SAGE Handbook of Grounded Theory. London, England: SAGE Publications.

Doherty, W. (2010). Mātauranga Tūhoe: the centrality of Mātauranga-a-iwi to Māori education. (Unpublished doctoral dissertation). University of Auckland, Auckland, New Zealand. 
Durie, M. H. (1985) A Māori perspective of health. Journal of Social Science and Medicine, 20(5), 483486.

Durie, M. H. (1997). Māori cultural identity and its implications for mental health services. International Journal of Mental Health, 26(3), 23-35.

Durie, M. H. (1998). Whaiora: Māori health development (2nd ed.). Auckland, New Zealand: Oxford University Press.

Durie, M. H. (2001). Mauri ora: The dynamics of Māori health. Auckland: Oxford University Press.

Durie, M. H. (2003). Ngā kahui pou: Launching Māori futures. Wellington, New Zealand: Huia Publishers.

Durie, M. (2012). Interview, kaupapa Māori: Shifting the social. New Zealand Journal of Educational studies. 47(2), 21-29.

Durie, M. H. \& Kingi, T. K. R. (1997) A framework for measuring Māori mental health outcomes (Report TPH 97/5). Wellington, New Zealand: Massey University

Elwafi, P. (2008). The Maori Ways of Traditional Healing: Tina Fraser interviewed by Paige Robbins Elwafi. Voices: A World Forum For Music Therapy, 8(3). doi:10.15845/voices.v8i3.422

Gluckman, P. (2011). Improving the transition: Reducing social and psychological morbidity during adolescence. A report from the prime minister's chief science advisor. Auckland: Office of the Prime Minister's Science Advisory Committee 
Gold, C., Voracek, M., \& Wigram, T. (2004). Effects of music therapy for children and adolescents with psychopathology: A meta-analysis. Journal Of Child Psychology And Psychiatry, 45(6), 10541063.

Heaton, J. (2008). Secondary analysis of qualitative data. In J. Brannen, L. Bickman \& P. Alasuutari (Eds.). The SAGE handbook of social research methods. London, England: SAGE Publications Ltd.

Heaton, S. (2011, January 1). The co-opting of hauora into curricula. Curriculum Matters, 7, 99-117.

Hutchings, J., Potter, H., \& Taupo, K. T. (Eds.). (2011). Kei Tua o Te Pae hui proceedings : the challenges of kaupapa Māori research in the 21st century, Pipitea Marae, Wellington, 5-6 May 2011. Wellington, N.Z: New Zealand Council for Educational Research.

Kahui, D. J. (2008). A cultural approach to music therapy in New Zealand: A Māori perspective. (Unpublished masters dissertation). Massey University, Te Kōkī NZ School of Music, Wellington, New Zealand.

Katene, T. P. (1991). Nga waiata manawa... Songs of the heart. Annual Journal of the New Zealand Society for Music Therapy, 13-20.

Kenny, C. (2002). Keeping the World in Balance - Music Therapy in a Ritual Context. Voices: A World Forum For Music Therapy, 2(2). doi:10.15845/voices.v2i2.84

Kenny, C. (2006). Music \& life in the field of play: An anthology. Gilsum, NH: Barcelona Publishers.

Kenny, C. (2014). The Field of Play: An Ecology of Being in Music Therapy. Voices: A World Forum For Music Therapy, 14(1). doi:10.15845/voices.v14i1.737 
Kenny, C. \& Hadley, S. (2013). Living and working between worlds. In S. Hadley (Ed.), Experiencing race as a music therapist. (pp. 17-28). Gilsum, NH: Barcelona Publishers.

King, M., Smith, A., \& Gracey, M. (2009). Indigenous health part 2: The underlying causes of the health gap. The Lancet, 374(9683), 76-85. doi:10.1016/S0140-6736(09)60827-8

Kingi, T. K. R. (2007). The Treaty of Waitangi: A framework for Māori health development. New Zealand Journal of Occupational Therapy, 54(1), 4-10.

Kirby, G. (1990). Cultural Identity and Health. Annual Journal of the New Zealand Society for Music Therapy, 21-23.

Kiro, C., Barton, R., Tauroa, P., Johanson, H., Ellison-Loschmann, L., Pearce, N. ... Belgrave, M. (2004). Te hauora o nga tamariki o Whaingaroa. (Occasional Report Series No 5). Kaeo, New Zealand: Te Runanga O Whaingaroa; Centre for Public Health research, Massey University.

Laycock, A., Walker, D., Harrison, N. \& Brands, J. (2011). researching Indigenous health: a practical guide for researchers. Carlton South, Australia: The Lowitja Institute.

Lennon, J., McCartney, P. (1968) Blackbird. On The Beatles (The White Album) [LP]. London, England: Apple Records.

Lennon, J., McCartney, P. (1969) Come Together. On Abbey Road [LP]. London, England: Apple Records.

Lennon, J., McCartney, P. (1970a) Across the Universe. On Let it Be [LP]. London, England: Apple Records.

Lennon, J., McCartney, P. (1970b) Let It Be. On Let it Be [LP]. London, England: Apple Records. 
Love, C. (2004). Extensions on Te Wheke. (Working Paper). Lower Hutt, New Zealand: The Open Polytechnic of New Zealand.

Marley, B. (1980). Redemption Song. On Uprising [LP]. Kingston, Jamaica: Tuff Gong Studios.

Marsden, M. (2003) Appendix three: A genealogy of the cosmos. In T. A. C. Royal (Ed.) The woven universe: Selected writings of Rev. Māori Marsden. Masterton, New Zealand: The Estate of Rev. Māori Marsden.

Mataira, K. T. H. (2000). Te tuakiri o te tangata. In Te Pōkaitahi Kaiako o Te Ataarangi (Kōeke 3)2008. Hamilton, New Zealand: Faculty of Te Ataarangi.

McFerran, K. (2010). Adolescents, music and music therapy. London, United Kingdom: Jessica Kingsley Publishers.

McIvor, M. (1988). New Directions Inspired by the Old: a Pakeha looks at Maori chant. Annual Journal of the New Zealand Society for Music Therapy, 3-9.

McIvor, M. (1998). Heroic Journeys: he taonga i kitea na te moemoea - a project exploring the use of therapeutic music and imagery with participants from the Maori culture. Annual Journal of the New Zealand Society for Music Therapiy, 27-36.

Mead, H. (2003). Tikanga Māori: Living by Māori values. Wellington, New Zealand: Huia Publishers.

Melbourne, H., Nunns, R., Yates-Smith, A. (2003) Te hekenga ā Rangi [CD \& DVD]. Auckland, New Zealand: Rattle.

Metge, J. (1986). In and out of touch: Whakamaa in cross cultural context. Wellington, New Zealand: Victoria University Press. 
Mikaere, A., \& Hutchings, J. (Eds.). (2013). Kei Tua o te Pae Hui proceedings : changing worlds, changing tikanga - educating history and the future, Te Wānanga o Raukawa, Ōtaki, 4-5 September 2012. Wellington, New Zealand: New Zealand Council for Educational Research ; Ōtaki, New Zealand: Te Wānanga o Raukawa.

Minister of Health, Associate Minister of Health. (2002). He korowai oranga: Māori health strategy. Wellington, New Zealand: Ministry of Health.

Minister of Health. (2005). Te Tāhuhu - Improving Mental Health 2005-2015: The Second New Zealand Mental Health and Addiction Plan. Wellington: Ministry of Health.

Ministry of Health. (2008). Te puāwaiwhero: the second Māori mental health and addiction national strategic framework 2008-2015. Wellington: Ministry of Health.

Morse, J. M. (2007). Sampling in grounded theory. In Charmaz, K., \& Bryant, A. (Eds.). The SAGE Handbook of Grounded Theory. London, England: SAGE Publications.

Nunns, R. (1995). Te Ara Puoro: the pathway of sound - a journey to bring forward the voices of Maori musical instruments. Annual Journal of the New Zealand Society for Music Therapy, 13-22.

Oakley Browne, M.A., Wells J.E., Scott K.M. (eds). (2006) Te Rau Hinengaro - The New Zealand Mental Health Survey. Wellington: Ministry of Health.

Page, J. \& Plant, R. (1975). Down By The Seaside. On Physical Graffiti [LP]. London, England: Swan Song records.

Pavlicevic, M., \& Ansdell, G. (2009). Between Communicative Musicality and Collaborative Musicing: Perspectives from Community Music Therapy. In S. Malloch \& C. Trevarthen (Eds.), Communicative Musicality. Oxford, England: Oxford University Press. 
Pihama, L. (2001). Tihei mauri ra: Honouring our voices. Mana wahine as a kaupapa Maori theoretical Framework. Unpublished PhD, The University of Auckland

O'Callaghan. C. (2012). Grounded theory in music therapy research. Journal of Music Therapy. 49(3). 236-277.

Pere, R. T. (1991). Te wheke: A celebration of infinite wisdom (2nd. ed.). Wairoa, New Zealand: Ao Ako Global Learning New Zealand Ltd.

Pohe, E. (2012). Whakawhanaungatanga a-reo: An indigenous grounded theory for the revitalization of Māori speech communities. (Unpublished doctoral thesis). Victoria University, Wellington, New Zealand.

Robbins, C. (2005). A journey into creative music therapy. Gilsum, NH: Barcelona Publishers.

Rollo, T. (2013a). Mā Te Wai - Ka Piki Ake Te Hauora. Paper presented at Linking Cultures: New Zealand School of Music (NZSM) Music Therapy Conference, Wellington, New Zealand. Retrieved from: http://vimeo.com/80754843

Rollo, T. (2013b). Mā Te Wai - Ka Piki Ake Te Hauora. New Zealand journal of music therapy, 11, 5180.

Royal, T. A. C.(2002). Indigenous Worldviews: A Comparative Study. Wellington, New Zealand: Te Wānanga-o-Raukawa.

Royal, T. A. A. (2006). A modern view of mana. In R. Nairn, P. Pehi, R. Black \& W. Waitoki (Eds.), $K a$ tu, ka oho: visions of a bicultural partnership in psychology (pp. 123-146). Wellington, New Zealand: The New Zealand Psychological Society. 
Ruud, E. (1995). Improvisation as a liminal experience: jazz and music therapy as modern "rites de passage”. In C. B. Kenny (Ed.) Listening, playing, creating: Essays on the power of sound (p. 91-117). Albany, NY: State University of New York Press.

Ruud, E. (1998). Music therapy: Improvisation, communication and culture. Gilsum NH: Barcelona Publishers.

Ruud, E. (2010). Music therapy: A perspective from the humanities. Gilsum, NH: Barcelona Publishers.

Sausser, S. \& Waller, R. J. (2006). A model for music therapy with students with emotional and behavioral disorders. The Arts in Psychotherapy 33(1), 1-10.

Small, C. (1998). Musicking: The meanings of performing and listening. Hanover: University Press of New England.

Smith, G. H. (2012). Interview, kaupapa Māori: The dangers of domestication. New Zealand Journal of Educational studies. 47(2), 10-20.

Smith, L. T. (2012) Decolonizing methodologies (2nd ed.). London, England: Zed Books.

Stephens, C., Porter, J., Nettleton, C., \& Willis, R. (2006). Disappearing, displaced, and undervalued: A call to action for indigenous health worldwide. The Lancet, 367(9527), 2019-2028. doi:10.1016/S0140-6736(06)68892-2

Stige, B. (2002). Culture-centered music therapy. Gilsum, NH: Barcelona Publishers.

Stige, B. (2003). Elaborations toward a notion of community music therapy. Oslo, Norway: Unipub AS.

Tervo, J. (2001). Music therapy for adolescents. Clinical Child Psychology and Psychiatry, 6(1). 79-91. 
Wenn, J. (2006). Kaupapa hauora Māori: Ngā whakaaro whakahirahira o ngā kaumātua (Unpublished doctoral dissertation). Massey University, Wellington, New Zealand.

Whakaatere, T. \& Pohatu, H. R. (2011). Mauri-Rethinking human well-being. MAI Review (3).

Retrieved from: http://www.review.mai.ac.nz/index.php/MR/article/view/380/680

Williamson, A., Andersen, M., Redman, S., Dadds, M., D’Este, C., Daniels, J., Raphael, B. (2014).

Measuring mental health in Indigenous young people: A review of the literature from 19982008. Clinical Child Psychology and Psychiatry, 19(2), 260-272.

doi:10.1177/1359104513488373

Wilson, S. (2008). Research is ceremony, indigenous research methods. Halifax, Canada: Fernwood Publishing.

Winnicott, D. W. (1991). Playing and reality. London, England: Routledge.

World Health Organisation (1999). The mental health of indigenous peoples: An international overview. Geneva, Switzerland: Department of Mental Health, World Health Organisation. 


\title{
Appendix One: Consent for Use of Information for Vignette
}

\author{
= \\ NEW Z E ALA N \\ SCHOOL \\ Music Therapy Programme (MMusTher) \\ Information Sheet
}

\section{Research Title: How does my music therapy practice in an acute mental health unit for adolescents relate to kaupapa Māori frameworks of health and wellbeing?}

\section{Dear}

As you know I am on placement here at as part of my music therapy studies. As part of my coursework I need to write an essay and create a small presentation based on my work here. My research for this will explore how kaupapa Māori approaches to health and wellbeing are related to the way that I work with individuals and groups. I will be writing about the music sessions I have run and also about other group activities I have been involved in such as art, poroporoaki (farewell), kapa haka, harakeke and cooking. If you agree, I would also like to write about your involvement in these activities.

I will base my writing on the clinical notes that I have taken during my time here. These are based on my observations and thoughts about our work together, including your actions or comments you might have made during our work together. For example, I might write something like this, using a pseudonym (a fake name): "Sue participated in all of our group music activities today but sang very quietly and did not volunteer to pick any songs or play solo at any time" or "Joseph concentrated for the entire hour while learning this song and told me that he often sings this song with his sister". Any personal or identifying information will be kept confidential and I will not include your name or the name/location of in my writing.

In December, I will submit what I have written to my examiners and after it has been marked it will be stored in the Massey and Victoria University libraries. If I am very successful, I may also present some of my research at an academic conference or publish an article in an academic journal.

When I have finished writing my essay, I will give the unit a copy of it as well as a smaller summary of my findings. If you would not like me to write about you then that is absolutely fine and this will not affect our work together at in any way. If you do agree, any data relating to our work together will be stored securely at the university and then destroyed 
after ten years. You are also welcome to contact me or my supervisor and withdraw your consent at any time. If you have any further questions please ask.

Yours sincerely,

Nolan Hodgson

\section{Consent Form}

Research Title: How does Kaupapa Māori theory relate to my music therapy practice in an acute mental health unit for adolescents.

I have read the information sheet

YES / NO

I have had the opportunity to discuss this and ask questions relating to this research

YES I

NO

I .................................. give consent for Nolan to write about me and the music

sessions that we have had together

YES I NO

I know that I can contact Nolan or his supervisor with the details below to ask further questions or to withdraw my consent at any time

YES / NO

Nolan's email address: hodgsonola@myvuw.ac.nz

Nolan's Supervisor:

Sarah Hoskyns

Music Therapy Programme Director, New Zealand School of Music

Phone: +64 48015799 ext 6410

Email: sarah.hoskyns@nzsm.ac.nz

Signed:

Print Name:

Date: 


\title{
Appendix Two: Parental Consent Form for Vignette.
}

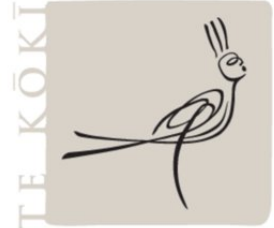 \\ NEW Z E A L A D \\ SCHOOL \\ Music Therapy Programme (MMusTher) \\ Information Sheet
}

\section{Research Title: How does my music therapy practice in an acute mental health unit for adolescents relate to kaupapa Māori frameworks of health and wellbeing?}

\section{Dear}

My name is Nolan Hodgson and I am on placement here at $\quad$ as part of my music therapy studies. As part of my coursework I need to write a research essay based on my work here. My research for this will explore how kaupapa Māori approaches to health and wellbeing are related to the way that I work with individuals and groups. I will be writing about the music sessions I have run and also about other group activities I have been involved in such as art, poroporoaki (farewell), kapa haka, harakeke and cooking. If you agree, I would also like to write about your child's involvement in these activities.

I will base my writing on the clinical notes that I have taken during my time here at the unit. These are based on my observations and thoughts about our work together, including actions or comments your child might have made during our work together. For example, I might write something like this, using a pseudonym (a fake name): "Sue participated in all of our group music activities today but sang very quietly and did not volunteer to pick any songs or play solo at any time" or "Joseph concentrated for the entire hour while learning this song and told me that he often sings this song with his sister". Any personal or identifying information will be kept confidential and I will not include any personal names or the name/location of in my writing.

In December, I will submit what I have written to my examiners and after it has been marked it will be stored in the Massey and Victoria University libraries here in Wellington. If I am very successful, I may also present some of my research at an academic conference or publish an article in an academic journal.

When I have finished writing my essay, I will give the unit a copy of it as well as a smaller summary of my findings. If you would not like me to write about your child then that is absolutely fine and this will not affect our work together at 1 in any way. If you do agree, any data relating to our work together will be stored securely at the university and then 
destroyed after ten years. You are also welcome to contact me or my supervisor and withdraw your consent at any time. If you have any further questions please ask.

Yours sincerely,

Nolan Hodgson

\section{Consent Form}

Research Title: How does Kaupapa Māori theory relate to my music therapy practice in an acute mental health unit for adolescents.

I have read the information sheet

YES / NO

I give consent for Nolan to write about

and the music sessions they have had together YES / NO

I know that I can contact Nolan or his supervisor with the details below to ask further questions or to withdraw my consent at any time YES / NO

Nolan’s email address: hodgsonola@myvuw.ac.nz

Nolan's Supervisor:

Sarah Hoskyns

Music Therapy Programme Director, New Zealand School of Music

Phone: +64 48015799 ext 6410

Email: sarah.hoskyns@nzsm.ac.nz

\section{Signed:}

\section{Print Name:}

\section{Date:}




\section{Appendix Three: Example of Deductive Codes from Data Analysis}

\begin{tabular}{|c|c|}
\hline $\begin{array}{l}\text { Wairua } \\
\text {-Identity-Sharing music (favourite } \\
\text { artists/tracks) } \\
\text {-Song-writing } \\
\text {-Improvisation } \\
\text {-Sharing cultural or religious songs } \\
\text {-Spiritual songs/waiata (Te Kaiwhakaora, } \\
\text { Hallelujah, Purea Nei Let it Be?). } \\
\text {-Leading the group, Kaea, calling } \\
\text {-Vocal work-unique voice/oro } \\
\text {-Mauri of instruments } \\
\text {-Songs associated with specific } \\
\text { areas/environments- able to take you to that } \\
\text { place, feel close to those people } \\
\text {-Non-Verbal sessions (1.7, 30.7) } \\
\text {-Idiosyncratic musical style/feel- across } \\
\text { instruments (1.7) } \\
\text {-getting lost in own world } \\
\text {-Wairua of the music (Beautiful is } \\
\text { 'depressing' 7.7, pursuit of Happiness is } \\
\text { 'motivating' 23.7) } \\
\text {-Connection to environment (8.7, 21.7, } \\
\text { Ngahere 9.7) }\end{array}$ & $\begin{array}{l}\text { Whānau } \\
\text {-Ensembles/groups/duos playing together, } \\
\text { staff/rangatahi } \\
\text {-Family members who play instruments } \\
\text {-Musical tastes drawn from family } \\
\text { members } \\
\text {-Family relationships described musically, } \\
\text { referred to through the music. 'The only hip- } \\
\text { hop song mum likes'. Brother/cousin/father } \\
\text { likes/plays this.23.7 \& } 28.7 \\
\text {-Carvings made for whānau }\end{array}$ \\
\hline $\begin{array}{l}\text { Tinana } \\
\text {-Body percussion } \\
\text {-Breathing/stretching before singing scales } \\
\text {-Clapping } \\
\text {-Interactive clapping games } \\
\text {-Foot-tapping } \\
\text {-Standing up } \\
\text {-Hygiene? OCD, symptoms involving } \\
\text { inability to use hands/limbs. } 28.7 \\
\text {-“Mahunga, Pakihiwi” This activity was } \\
\text { enjoyed ONCE IT BEGAN, reluctance } \\
\text { Non-verbal sessions } \\
\text {-Physical proximity- moving around } \\
\text { the room in sessions } \\
\text {-Physicality of instruments- Piano tinana } 7.7\end{array}$ & $\begin{array}{l}\text { Hinengaro } \\
\text { Theory-Inverted chords } \\
\text {-Developing melody using scale degrees } \\
\text {-Improvising using scales } \\
\text {-Adhering to rules of unit/acknowledging } \\
\text { external boundaries } \\
\text {-Clapping during scale singing } \\
\text {-Remembering chords on } \\
\text { guitar/ukulele/mandolin/piano } \\
\text {-Complex polyrhythms, hemiola. } \\
\text {-Remembering songs \& chord sequences- } \\
\text { conflict between this cognitive ability and that } \\
\text { reported in schoolwork/other domains. } 15.7 \& \\
28.7 \\
\text {-Getting lost in own world }\end{array}$ \\
\hline
\end{tabular}




\section{Appendix Four: Example of Analytic Memos}

\section{Note: ' $R$ ' stands for Rangatahi (adolescent).}

\begin{tabular}{|l|l|l|}
\hline & Experience or interaction & Analytic Memo exploring this \\
\hline 5.5 & $\begin{array}{l}\text { 'Time of your life' and } \\
\text { discussion of how it was one } \\
\text { of the first songs I learnt on } \\
\text { guitar }\end{array}$ & $\begin{array}{l}\text { Sharing musical history/experiences. These instances } \\
\text { build rapport, musical links. Iho matua }\end{array}$ \\
\hline 5.5 & $\begin{array}{l}\text { Not confident in her abilities } \\
\text { at school }\end{array}$ & $\begin{array}{l}\text { Performance in MT contradicts this, very capable } \\
\text { learner. Context specific abilities. }\end{array}$ \\
\hline 5.5 & $\begin{array}{l}\text { To finish I played it on the } \\
\text { piano so she couldn't just } \\
\text { follow my fingers }\end{array}$ & $\begin{array}{l}\text { Therapeutic technique? Teach them and support their } \\
\text { playing then move away, play quieter/less/another } \\
\text { instrument. This gives them control and independence. } \\
\text { Are able to do this easily within structure of a song once } \\
\text { they have a repetitive phrase down. Idea of facilitating } \\
\text { their own well-being, they heal themselves- Korero from } \\
\text { Rongoa Māori session. }\end{array}$ \\
\hline 5.5 & $\begin{array}{l}\text { Composing a collage and } \\
\text { explained that it was all } \\
\text { about him and his father }\end{array}$ & $\begin{array}{l}\text { Creative process again, used to externalise family } \\
\text { relationships-whānau. }\end{array}$ \\
\hline 6.5 & Discussing short story & Another instance of exploring R's creative work \\
\hline 6.5 & $\begin{array}{l}\text { Sustained a conversation } \\
\text { across the table }\end{array}$ & $\begin{array}{l}\text { Table tennis after a music session- sustaining a } \\
\text { conversation was significant for this R. Again the period } \\
\text { after a session opened up another opportunity. }\end{array}$ \\
\hline 6.5 & $\begin{array}{l}\text { R \& I explained how to play } \\
\text { the little fills that go } \\
\text { between the lyrics }\end{array}$ & $\begin{array}{l}\text { Peer support- R assisting me with her musical } \\
\text { knowledge to aid her peer. Tuakana-teina relationship. }\end{array}$ \\
\hline
\end{tabular}

\begin{tabular}{|l|l|l|}
\hline 6.5 & $\begin{array}{l}\text { Played the xylophone...took } \\
\text { a shaker }\end{array}$ & $\begin{array}{l}\text { These are 'safe' instruments. Easy to use and blend in } \\
\text { with other music being played. }\end{array}$ \\
\hline 6.5 & $\begin{array}{l}\text { Saying she 'couldn't do it' } \\
\text { initially when offered the } \\
\text { rākau again she was one of } \\
\text { the most capable. }\end{array}$ & $\begin{array}{l}\text { Change here, willingness to try something before } \\
\text { dismissing their ability. }\end{array}$ \\
\hline 6.5 & Improvising sounds to a & Ability to incorporate other creative pursuits into \\
\hline
\end{tabular}




\begin{tabular}{|c|c|c|}
\hline & book reading. & $\begin{array}{l}\text { musical activities. Reading/writing. Performing this } \\
\text { creatively and expressively with instruments. } \\
\text { Importance of this adaptability, nāku te rourou }\end{array}$ \\
\hline 6.5 & $\begin{array}{l}\text { Taking cajon over to corner } \\
\text { of room. }\end{array}$ & $\begin{array}{l}\text { Withdrawl- physically removing himself from the } \\
\text { limelight, the centre. }\end{array}$ \\
\hline 12.5 & Very Significant session! & $\begin{array}{l}\text { Self-initiated. Two very acutely unwell R joined me in } \\
\text { the music room without me asking and participated very } \\
\text { comfortably and respectfully, significantly considering } \\
\text { their usual behaviours. What is the value of letting them } \\
\text { choose the moment like this? This created opportunities } \\
\text { for them to see what was available in the music room. } \\
\text { From these interactions I could then arrange more } \\
\text { formal 'sessions' at specific times. }\end{array}$ \\
\hline 12.5 & Poetry \& carving sessions. & $\begin{array}{l}\text { Building rapport again through engaging with } \mathrm{R} \text { during } \\
\text { other creative activities. }\end{array}$ \\
\hline 12.5 & $\begin{array}{l}\text { Linking ind. and group work } \\
\text { with self-composed song. }\end{array}$ & $\begin{array}{l}\text { Supported R with their song, suggested alternative ways } \\
\text { of playing it/accenting it and asked to share in group. } \\
\text { Weaving of individual and group sessions } \\
\text { Also piano work for 'Someone Like You' }\end{array}$ \\
\hline 12.5 & Group improvisations. & $\begin{array}{l}\text { Three of these, all discussed and reflected on as a group. } \\
\text { We obviously became more attuned to each other as we } \\
\text { continued. Third improv. appreciated much more than } \\
\text { the first. Difficulties with leading/bass drum/cajon } \\
\text { playing. Liminality here- identity, improvisational } \\
\text { identity, character in that moment, changes state/mood } \\
\text { of group/individuals. }\end{array}$ \\
\hline 12.5 & $\begin{array}{l}\text { Seemed a bit reluctant, } \mathrm{R} \\
\text { sang her song for everyone } \\
\text { and received some positive } \\
\text { feedback from peers }\end{array}$ & $\begin{array}{l}\text { Overcame their fear/nerves and was encouraged by peers } \\
\text { for sharing like this. Became more confident second } \\
\text { time around after this. Tuakana/Teina. }\end{array}$ \\
\hline 12.5 & Blackbird & $\begin{array}{l}\text { R spontaneously began playing this, group was largely } \\
\text { surprised and certainly appreciative. }\end{array}$ \\
\hline
\end{tabular}

